TITLE:

\title{
Ecogeographical and phylogenetic effects on craniofacial variation in macaques.
}

$\operatorname{AUTHOR}(S)$ :

Ito, Tsuyoshi; Nishimura, Takeshi; Takai, Masanaru

\section{CITATION:}

Ito, Tsuyoshi ... [et al]. Ecogeographical and phylogenetic effects on craniofacial variation in macaques.. American journal of physical anthropology 2014, 154(1): 27-41

\section{ISSUE DATE:}

2014-01-22

URL:

http://hdl.handle.net/2433/198636

\section{RIGHT:}

This is the peer reviewed version of the following article: Ito, T., Nishimura, T. and Takai, M. (2014), Ecogeographical and phylogenetic effects on craniofacial variation in macaques. Am. J. Phys. Anthropol., 154: 27-41, which has been

published in final form at http://dx.doi.org/10.1002/ajpa.22469.; この論文は著者最終稿です。内容が印刷版と異なるこ とがありますので、引用の際には出版社版をご確認じ利用ください。This is the Accepted Author Manuscript. Please cite only the published version. 


\section{Ecogeographical and phylogenetic effects on craniofacial variation in macaques}

Tsuyoshi Ito, Takeshi Nishimura, Masanaru Takai

Primate Research Institute, Kyoto University, Inuyama, Aichi 484-8506, Japan

44 text pages, 7 figures, 6 tables.

Abbreviated title: Craniofacial variation in macaques

Key words: biogeography; adaptive convergence; allometry; Bergmann's rule; geometric

morphometrics

Corresponding author: Tsuyoshi Ito

Primate Research Institute, Kyoto University, Inuyama, Aichi 484-8506, Japan

Tel \& Fax: +81-568-63-0536

E-mail: ito.tsuyoshi.3r@ kyoto-u.ac.jp

This study was financially supported by AS-HOPE and ITP-HOPE Programs from JSPS

(to T. I.), Grant-in-Aid for JSPS Fellows (to T. I.), Grant-in-Aid for Challenging Exploratory

Research (to T. N.), and Global COE Program from MEXT (Grant A06 to Kyoto University). 


\section{ABSTRACT}

The widespread and complex ecogeographical diversity of macaques may have caused adaptive morphological convergence among four phylogenetic subgroups, making their phylogenetic relationships unclear. We used geometric morphometrics and multivariate analyses to test the null hypothesis that craniofacial morphology does not vary with ecogeographical and phylogenetic factors. As predicted by Bergmann's rule, size was larger for the fascicularis and sinica groups in colder environments. No clear size cline was observed in the silenus and sylvanus groups. An allometric pattern was observed across macaques, indicating that as size increases, rounded faces become more elongated. However, the elevation was differentiated within each of the former two groups and between the silenus and sylvanus groups, and the slope decreased in each of the two northern species of the fascicularis group. All allometric changes resulted in the similar situation of the face being more rounded in animals inhabiting colder zones and/or in animals having a larger body size than that predicted from the overarching allometric pattern. For non-allometric components, variations in prognathism were significantly correlated with dietary differences; variations in localized shape components in zygomatics and muzzles were significantly correlated with phylogenetic differences among the subgroups. The common allometric pattern was probably influenced directly or indirectly by climate-related factors, which are pressures favoring a more rounded face in colder environments and/or a more elongated face in warmer 
environments. Allometric dissociation could have occurred several times in Macaca even within a subgroup because of their wide latitudinal distributions, critically impairing the taxonomic utility of craniofacial elongation. 


\section{INTRODUCTION}

Craniofacial morphology widely varies among extant macaque monkeys (Macaca spp.) (Albrecht, 1978; Pan et al., 1998; Pan and Oxnard, 2000, 2001, 2002). Craniofacial features have been used to taxonomically identify fossil macaques (Schlosser, 1924; Iwamoto, 1975; Delson, 1977; Fooden, 1990; Rook and O'Higgins, 2005); however, classification is occasionally controversial (Delson, 1980; Jablonski and Pan, 1988; Jablonski, 2002), possibly because of some homoplastic features related to their salient and complicated ecogeographical diversity.

Macaques are distributed across a wide range of climates from tropical to temperate zones. Such a wide distribution is not found in any other primate genus except humans (Fleagle, 1999). Approximately 20 species of extant macaques are phylogenetically classified into four species groups (i.e., sylvanus, silenus, sinica, and fascicularis groups) based on genitalia, cranial morphology, biogeography, and fossil records (Fooden, 1976; Delson, 1980) (Fig. 1A; Table 1). This traditional classification is supported by recent molecular studies (Tosi et al., 2000, 2003; Li et al., 2009) (Fig. 1B-D). The sylvanus group (M. sylvanus) is distributed in a small temperate region of northern Africa (Fooden, 2007). The silenus group is found in tropical areas of southern India and from Sundaland to Indochina (Fooden, 1969, 1975). The sinica group occupies tropical India and Sri Lanka and also inhabits subtropical and temperate areas between Nepal and eastern China (Fooden, 1985, 1990). The fascicularis 
group has the widest continuous distribution, ranging from tropical Indonesia to subtropical and temperate areas between eastern Afghanistan and Japan (Fooden, 2006). Notably, the latitudinal distribution ranges of the four species groups considerably overlap, and the species groups often share similar climatic conditions. This observation suggests that geographic dispersal among various climatic conditions has independently occurred for each species group rather than accompanying species group divergence.

Such a complex ecogeographical diversity, which is independent of phylogenetic (among the species groups) divergence, inevitably obscures phylogenetic value of some morphological features. For example, each species group would have independently modified its craniofacial morphology in response to the varied environmental conditions, which may have caused convergent evolution among the species groups.

One of the major convergent factors is a latitudinal gradient in body mass (Albrecht, 1980; Fooden, 1988; Fooden and Albrecht, 1993; Hamada et al., 1996; Fooden, 2006). This gradient is usually explained by Bergmann's rule, which predicts that animals living in northern, colder environments have a larger body size than those living in southern, warmer regions, as a physiological adaptation to effectively maintain body temperature. This latitudinal gradient in body mass is strongly correlated with craniofacial shape variation across macaques, except for Sulawesi macaques, which have an extremely unusual craniofacial shape (Albrecht, 1978). Positive facial allometry, indicating that the face 
elongates relatively more with size, has been reported in several macaque species (Pan et al., 2003). Such allometric scaling probably caused significant convergence among the species groups. Despite belonging to different species groups, small-bodied macaques (i.e., M. sinica, M. radiata, and $M$. fascicularis) have numerous craniofacial shape similarities and are distinguished from large-bodied species (Pan and Oxnard, 2000, 2001). Thus, allometric scaling amplified by the effect of Bergmann's rule is probably the most effective factor in the formation of homoplastic craniofacial features among the species groups.

Other aspects of the effect of latitudinal environmental differences may also contribute to a convergence among the species groups with respect to craniofacial morphology. For example, because Allen's rule predicts that a more elongated body part is more liable to lose body heat than a more rounded one, animals in northern and colder environments may be under a selection pressure that favors a more rounded face with a shorter muzzle (as shown in the short muzzle of the arctic fox; Prestrud, 1991). A dietary shift is another possible cause of craniofacial modifications with latitude (Antón, 1996). Thus, even if the allometric effect is adjusted for, craniofacial shape possibly reflects latitudinal environmental differences that obscure phylogenetic information.

Overall, craniofacial shape variations among extant macaque species groups potentially contain a considerable number of homoplastic features caused by convergent evolution along latitudinal environmental gradients. In the present study, we investigated how environmental 
factors influence craniofacial morphology in extant macaques in order to obtain a better understanding of the factors that underlie phenotypic variation and to evaluate the potential use of craniofacial shape in the taxonomic (species group) identification of fossil specimens. We distinguished among size, allometric variations, and non-allometric variations because environmental pressures can affect each of these three components independently and differently. Our null hypothesis is that none of the three components varies with ecogeographical or phylogenetic factors. We tested this null hypothesis for a better understanding of the factors that underlie phenotypic variations in extant macaques.

\section{MATERIALS AND METHODS}

\section{Cranial samples and landmark coordinates}

We examined 12 species of macaques, excluding Sulawesi macaques. We used 549 (243 female and 306 male) adult dry crania with erupted third molars (Table 2). The animals were shot or sampled in the wild. M. fascicularis, M. mulatta, M. fuscata, M. assamensis, and M. nemestrina individuals were divided into two or three populations based on geography and/or genetic distances, and the populations were regarded as sampling units (Table 2; Fig. 2) because they occupy wide ranges and/or have considerable genetic differentiation among populations (for references refer to Supporting information). Specimen samples for the other 
species were not subdivided, and the species themselves were regarded as sampling units. We randomly selected specimens by a sampling unit (i.e., population or species) from as many localities as possible and reduced the number to approximately 20 per sex to avoid statistical artifacts related to sample size.

Three-dimensional cranial surface landmark coordinates were measured using a three-dimensional digitizer (Microscribe MX; Immersion Corp., San Jose, CA, USA). Of the 33 landmarks defined in Table 3, 23 were from the face and eight were from the neurocranium (the glabella was included in both sets of the face and the neurocranium) (Fig. 3). Only measurements on the left side were used to avoid redundancy, but horizontal reversals of the right-side measurements were used for specimens with broken left sides. Missing landmarks were estimated using mean sampling unit coordinate values by sex following registration procedures (see Slice, 1999; Cardini and Elton, 2008).

\section{Ecogeographical and phylogenetic data}

The geographic coordinate for each specimen was defined as the approximate center of the province, state, region, prefecture, district, or island that encompassed the sampling location. If the approximate center of the political jurisdiction or island was outside the actual distribution range of the species/population, the geographic coordinate was redefined as the approximate center of the overlapping area between the actual distribution range and the 
political jurisdiction or island. Annual mean temperatures were taken from the BIOCLIM database on the WorldClim website (Hijmans et al., 2005; http://www.worldclim.org/) using the DIVA-GIS software (http://www.diva-gis.org/). The absolute value of the latitudinal coordinate was used in the following analysis, substituted for annual mean temperature because annual mean temperature can potentially reflect microscale regional outliers and localization artifacts that do not have evolutionary significance. Nevertheless, the results using annual mean temperature were similar and therefore not shown.

For phylogenetic data, the phylogenetic relationship revealed by Alu elements \{sylvanus group, [silenus group, (sinica group, fascicularis group)]\} (Fig. 1D; Table 1), was used because it is robust; this robustness is because the Alu elements show very little homoplasy and their ancestral state is known (Li et al., 2009). The phylogenetic relationship within a species group was not considered because of its uncertainty and was treated as a polytomy.

Categorical data were taken from the literature and summarized in Table 1 (refer to Supporting information).

\section{Size variation}

Centroid size (CS) for each specimen was calculated as the square root of the sum of the squared Euclidean distances from each landmark to the centroid. CS was calculated for each landmark set from the face, neurocranium, and entire cranium. 
We regressed the natural logarithm of species average (split sex) body mass (g) against

the natural logarithm of species average (split sex) CS for each of the three cranial regions to evaluate which cranial region was the most appropriate body mass predictor. Among the three regressions, the one that best explained the body mass data was selected (Fig. 4A). The coefficient (slope) for the selected regression was used to predict each individual's body mass, where an intercept was defined respectively for each species (split sex) so that a regression line passed through the coordinate of each species average (split sex). A body size surrogate was calculated as a predicted value by substituting each individual's $\operatorname{lnCS}$ for the independent variable in the regression equation that was defined for the species (split sex) to which the individual belonged (Fig. 4B). Body mass averages were primarily obtained from Delson et al. (2000); the data for M. cyclopis were from Fooden and Wu (2001).

A multivariate regression analysis was performed for the entire sample to evaluate factors influencing body size; the dependent variable was the body size surrogate, and the independent variables were sex, species group, habitat use type, and annual mean temperature. Sex and species group were nominal and thus respectively coded as dummy variables (e.g., if an individual belonged to the sinica group, it was coded as 1 ; if not, it was coded as 0 ). Habitat use type was an ordinal scale variable, where "arboreal" was coded as 0 , "intermediate or uncertain" as 1 , and "terrestrial" as 2. Diet was excluded as an independent variable because it was highly correlated with annual mean temperature $(\mathrm{r}=-0.71, \mathrm{p}<0.001)$ 
and was not likely to be a direct factor affecting body size. We performed the same analyses for each species group.

\begin{abstract}
Allometric variation
Standard geometric morphometric methodological approaches (Mitteroecker and Gunz, 2009; Zelditch et al., 2012) were employed. A generalized Procrustes analysis (Rohlf and Slice, 1990) was conducted to register landmark configurations of the face (23 landmarks). The registered data, i.e., Procrustes shape coordinates, were used as shape variables in the following analyses.
\end{abstract}

Multivariate allometric patterns of craniofacial shape variation have been studied using several methods. One of the most commonly used is based on the principal component analysis (PCA) of the covariance matrix of Procrustes shape coordinates. In this case, the first principal component (PC1), which accounts for the maximum variance, is usually plotted and/or regressed against a size variable to explore an allometric pattern (O'Higgins and Jones, 1998; Singleton, 2002). This approach is adequate when an allometric (size-correlated) component is relatively dominant in total variation, as in an ontogenetic sample or in a sample that has great size variation and is relatively homogeneous. However, depending on the nature of the sample, there is a risk that an allometric component is unexpectedly shared with PCs other than PC1, whereas PC1 contains some of the non-allometric variation. Because an 
allometric component may not be dominant in total variation in our data, we instead applied the multiple regression of Procrustes shape coordinates (Monteiro, 1999). The multiple regression detects shape variation that the independent variable (size, in this case) best explains, which suits our aim and samples.

The multiple regression of the Procrustes shape coordinates for the face on the body size surrogate with a 10,000 times permutation test was performed for the entire sample to explore a common allometric pattern across macaques (MorphoJ; Klingenberg, 2011). Herein, shape scores, which are analogous to the PC1 scores in the study of allometry, were computed for all individuals. The shape score was defined as $s=y b^{\mathrm{T}}\left(b^{\mathrm{T}} b\right)^{-0.5}$, where $b^{\mathrm{T}}$ is the transposed matrix of $b$ (MorphoJ; Drake and Klingenberg, 2008; Klingenberg, 2011) when considering the regression equation $y=b x+e$, where $y$ is the vector of shape variables, $b$ is the regression vector, $x$ is the size variable, and $e$ is the error term. This is a projection of the shape variable vector onto regression vector $b$ and can be interpreted as the shape variable that is most strongly associated with the size variable. Nevertheless, the shape score includes the residual variation in that direction. We examined the allometric pattern and its residual variation by plotting the shape scores against the body size surrogates. To evaluate the factors influencing differences in the allometric pattern (i.e., factors contributing to residual variations), the homogeneity of slopes and elevations for the least-squares regression of the shape scores on the body size surrogates was tested between the two climatic zones, among the four species 
groups, among species within a species group, and between each species and a general pattern (a climatic zone).

The same analyses were conducted by regression of the PC1 scores on the body size surrogates following PCA of the covariance matrix for the Procrustes shape coordinates for the face to compare with previous studies.

\section{Non-allometric (and sex-adjusted) variation}

We performed multiple multivariate regression of the Procrustes shape coordinates for the face on the body size surrogate and sex, where sex was coded as a dummy variable (i.e., 0 or 1) to correct for the effect of sex and size on face shape. Residuals from the regression were calculated and used as size- and sex-adjusted shape variables (MorphoJ; Klingenberg, 2011)

The Mantel test (Mantel, 1967) was performed among all 19 sampling units to evaluate the association between shape and ecogeographical/phylogenetic factors. This test examines the correlation between the distance matrices of two of these variables. Shape distances were calculated as Mahalanobis squared distances of the size- and sex-adjusted shape variables. Climatic distances were calculated as Euclidean distances of the unit average for annual mean temperature, which was standardized. Dietary distances were calculated as Gower's distances (Gower, 1971) because these data are binary (i.e., the distances between "hard food eaters" 
and "the others" were 1, and between the same values were 0). Phylogenetic distances were calculated as ultrametric distances (i.e., distances within a species group, between the sinica and fascicularis groups, between the silenus and sinica/fascicularis groups, and between the sylvanus group and the other groups were 1, 2, 3, and 4, respectively). The Mantel test with 100,000 random permutations was performed between the shape distances and the phylogenetic/climatic/dietary distances. Furthermore, a three-way Mantel test with 100,000 random permutations was performed (Smouse et al., 1986) to calculate the partial correlation between the shape distances and the climatic/dietary distances, while holding the effect of phylogeny constant. This was done to detect the true effect of climate/diet on shape by factoring out the confounding phylogenetic effect.

Canonical variate analysis (CVA) with 10,000 random permutations was performed for the size- and sex-adjusted shape variables to identify the shape features that best distinguished the four species groups and dietary differences.

Shape variations assessed by the multiple regression and CVA were represented by deformations of the Cartesian transformation grids calculated from triplets of thin plate splines (TPS; Bookstein, 1989; O'Higgins and Jones, 1998). The grids derived from TPS show how the space surrounding a reference shape is deformed into the space surrounding a target shape using minimum bending energy. The space deformations were further visualized 
by reconstructing hypothetical forms of a wireframe and by smooth surface rendering of polygons.

These analyses were performed using Morpheus et al. (Slice, 1999), MorphoJ (Klingenberg, 2011), Morphologika ver. 2.5 (O'Higgins and Jones, 1998, 2006), NTSYSpc ver. 2.21a (Rohlf, 2005), and R software with the "cluster" and package.

\section{RESULTS}

\section{Size variation}

The natural logarithm of species average (split sex) body mass was better explained by neurocranial $\operatorname{lnCS}\left(\mathrm{R}^{2}=0.84, \mathrm{p}<0.001, \mathrm{y}=5.0191 \mathrm{x}-13.763\right.$; Fig. 4A) than by facial $\operatorname{lnCS}$ $\left(\mathrm{R}^{2}=0.75, \mathrm{p}<0.001\right)$ or entire cranial $\operatorname{lnCS}\left(\mathrm{R}^{2}=0.78, \mathrm{p}<0.001\right)$. Thus, the body size surrogate was calculated for each individual on the basis of the neurocranial lnCS (Fig. 4B).

The factors influencing body size are listed in Table 4. The size variation in the entire sample was significantly explained by annual mean temperature as well as differences in sex, species group, and habitat use type. The (standard) partial regression coefficient indicated that size was larger under colder climatic conditions, in males than in females, in terrestrial animals than in arboreal animals, and in the silenus group $>$ the sinica group $>$ the fascicularis group (the sylvanus group was less significant). According to the standard partial regression 
coefficient values for the fascicularis and sinica groups, climatic factors were considerably more effective predictors than sex and habitat use type. In contrast, climatic factors were less effective than sex and habitat use type for the silenus group. The contribution of sex was tested (40\% was explained) for the sylvanus group, but the other factors were not tested because of the group's limited distribution and single habitat use type.

\begin{abstract}
Allometric variation
Multiple regression analysis revealed that $8.8 \%$ of the total variance of the Procrustes shape coordinates was explained by the body size surrogate for the entire sample $(p<0.001)$, indicating that this regression vector represented a common allometric pattern across macaques. Increasing shape scores represented shape modifications; the upper face became smaller in width and length relative to the lower face, the muzzle was relatively longer, and the anterior portion of the face tilted more inferiorly, a feature known as klinorhynchy (Fig. 5A). Taken together, these findings indicate that as size increases, a rounded face becomes more elongated.
\end{abstract}

The homogeneity of slopes and elevations was tested for the least-squares regression of the shape scores on the body size surrogates. The slopes were not different between the two climatic zones ( $d f=1, F=0.415, p=0.52$; Fig. 5B), but elevations were significantly higher for animals in tropical zones than for animals in subtropical/temperate zones $(\mathrm{t}=14.69, \mathrm{p}<$ 
0.001; Fig. 5B). In contrast, the slopes were significantly different among the four species groups $(\mathrm{df}=3, \mathrm{~F}=8.401, \mathrm{p}<0.001$; Fig. $5 \mathrm{C})$. The slope of the fascicularis group was significantly lower than those of the sinica group $(\mathrm{df}=1, \mathrm{~F}=7.969, \mathrm{p}=0.005)$ and the silenus group $(\mathrm{df}=1, \mathrm{~F}=19.61, \mathrm{p}<0.001)$. The slope of the sinica group was significantly lower than that of the silenus group $(\mathrm{df}=1, \mathrm{~F}=6.603, \mathrm{p}=0.011)$, although this difference was not significant either at adjusted Bonferroni $\mathrm{p}<0.05$ or after removing $M$. sinica, whose regression was not significant $(\mathrm{df}=1, \mathrm{~F}=2.549, \mathrm{p}=0.112$ ). The slope of the sylvanus group appeared to be identical to that of the silenus group and higher than those of the other two groups (Fig. 5C), although these differences did not reach statistical significance, probably in part because of the limited sample size. The elevation of the silenus group was significantly higher than that of the sylvanus group $(\mathrm{t}=-6.852, \mathrm{p}<0.001)$.

Regressions for each species are summarized in Table 5. The slopes were significantly different among species within the fascicularis group ( $\mathrm{df}=3, \mathrm{~F}=3.996, \mathrm{p}=0.008$; Fig. 5D), with $M$. fascicularis $>$ M. mulatta $(\mathrm{df}=1, \mathrm{~F}=6.951, \mathrm{p}=0.009)$ and $M$. fascicularis $>M$. fuscata $(\mathrm{df}=1, \mathrm{~F}=7.133, \mathrm{p}=0.008)$. The slopes were not different between $M$. fascicularis and $M$. cyclopis $(\mathrm{df}=1, \mathrm{~F}=0.012, \mathrm{p}=0.915)$, but the elevation was significantly higher for the former than for the latter $(\mathrm{t}=-8.188, \mathrm{p}<0.001)$. The slopes were not different among species within the sinica group after removing $M$. sinica $(\mathrm{df}=3, \mathrm{~F}=0.715, \mathrm{p}=0.545)$. Elevations seemed to be higher for M. radiata and M. assamensis than for M. arctoides and $M$. 
thibetana (Fig. 5E); they were significantly different between M. assamensis and M. thibetana $(\mathrm{t}=-3.768, \mathrm{p}<0.001)$, between $M$. assamensis and $M$. arctoides $(\mathrm{t}=6.173, \mathrm{p}<0.001)$, and between $M$. radiata and $M$. arctoides $(\mathrm{t}=-2.683, \mathrm{p}=0.01)$, although the last one was not significant at adjusted Bonferroni $\mathrm{p}<0.05$. Most $M$. sinica individuals tended to be scattered along or above the M. radiata and M. assamensis regression lines, although without statistical significance (Fig. 5E). The two species within the silenus group had similar slopes $(\mathrm{df}=1, \mathrm{~F}$ $=0.855, \mathrm{p}=0.358)$ and elevations $(\mathrm{t}=0.396, \mathrm{p}=0.693)($ Fig. $5 \mathrm{~F})$.

The slopes of most species were not significantly different from the general one, i.e., the slope of the climatic zone to which a species belongs (Table 5). However, slopes were significantly lower in M. mulatta and M. fuscata than in the general one. Slopes appeared to be higher in M. assamensis, M. thibetana, and M. nemestrina than in the general one, although these differences did not reach statistical significance, probably in part because of the limited sample size.

Similar results, including the pattern of shape change, the parallel shift in the allometric trajectory between the two climatic zones, the pattern of slope dissociation among the four species groups, and their levels of statistical significance were also obtained from the regression analysis of PC1 scores on body size surrogates (detailed results not shown). However, PC1, which accounted for $29.1 \%$ of the total variance, demonstrated a larger amount of residual variation and thus was indicative of the inclusion of some non-allometric 
components.

\section{Non-allometric (and sex-adjusted) variation}

The size- and sex-adjusted shape variables (i.e., residuals from the multiple multivariate regression of the Procrustes shape coordinates against the body size surrogate and sex; $15.6 \%$ was explained, $\mathrm{p}<0.001)$ were tested for a correlation with ecogeographical and phylogenetic factors. The Mantel test revealed that the correlations between shape distances and phylogenetic distances were higher $(\mathrm{r}=0.52, \mathrm{p}=0.001)$ than those with dietary distances $(\mathrm{r}=$ $0.30, \mathrm{p}=0.039)$ and climatic distances $(\mathrm{r}=0.19, \mathrm{p}=0.077)$. The three-way Mantel test revealed that when controlling for phylogenetic effects, the correlation between shape distances and climatic distances was not significant $(\mathrm{r}=0.13, \mathrm{p}=0.147)$, whereas that with dietary distances was weak but significant $(\mathrm{r}=0.27, \mathrm{p}=0.037)$.

CVA demonstrated that the first three canonical variates accounted for $54.3 \%, 26.6 \%$, and $19.1 \%$ of the total among-group variance, respectively. The first canonical variate (CV1) distinguished the fascicularis and sylvanus groups from the sinica and silenus groups (Fig. 6A). The former two groups represented relatively higher and wider upper muzzles than the latter two groups (Fig. 6B). CV2 distinguished the sinica group from the silenus group, whereas the fascicularis and sylvanus groups were intermediate between them (Fig. 6A). The silenus group exhibited a relatively narrow zygomatic and anteriorly convex nasal profile line, 
and the sinica group showed the opposite features (Fig. 6C). CV3 distinguished the sylvanus group from the others (Fig. 6D). The zygomatic was positioned more posterolaterally in the sylvanus group as compared to the others (Fig. 6E). Overall, the sylvanus group consistently showed the largest Mahalanobis and Procrustes distances from the other groups; distances between the fascicularis and sinica groups were smaller than the distances between the silenus group and either the fascicularis or sinica groups (Table 6).

CVA also revealed that the hard-food eaters exhibited an anteroposteriorly shorter, narrower, and vertically higher (i.e., less prognathic) face than the others (Mahalanobis distance: $r=2.2179, p<0.001$; Procrustes distance: $r=0.0339, p<0.001 ;$ Fig. 7).

\section{DISCUSSION}

We used geometric morphometrics and multivariate analyses to comprehensively assess ecogeographical and phylogenetic factors influencing size, allometric variations, and non-allometric variations in the facial cranium of extant macaques. Our null hypothesis was rejected, indicating that each of the three components is significantly influenced by ecogeographical and phylogenetic factors. Prior studies also applied geometric morphometrics to distinguish between allometric and non-allometric patterns in craniofacial shape but on a limited number of species (Pan et al., 2003; Rook and O'Higgins, 2005; Ito et al., 2011; 
Singleton, 2012). With its large sample size encompassing 12 species, our analysis provides greater insight into craniofacial variation and its potential use in taxonomic (species group) identification of fossil macaques.

Body size was estimated by cranial measurements and is the most obvious limitation of our analysis. Nevertheless, cranial measurements, including CS and length, have been used as a surrogate for body size in numerous primate studies (e.g., Singleton, 2002; Schillaci et al., 2009; Cardini et al., 2013). We estimated body size using neurocranial lnCS because species average body mass was more highly correlated with neurocranial size than with facial or entire cranial sizes (see also Delson et al., 2000). Although the estimated values could potentially overestimate or underestimate individual body size, the values were reasonable surrogates for body size considering the limited availability of individual body mass data.

Geographic variation in body size has been studied in several primate taxa. Evidence for Bergmann's rule, namely latitude- or temperature-related size variation, has been detected in some high taxonomic (Subfamily to Order) levels in primates (Harcourt and Schreier, 2009). However, this was driven by Old World monkeys, including macaques, and was not significant when phylogenetic effects were controlled for in Colobinae (Harcourt and Schreier, 2009) and Malagasy primates (Kamilar et al., 2012). Bergmann's rule has been reported for the genus Nycticebus (Ravosa, 1998), Aotus azarai (Fernandez-Duque, 2011), and Microcebus murinus (Lahann et al., 2006). These taxa are small in body size and therefore are 
probably sensitive to ambient temperature in terms of regulating body temperature. However, Bergmann's rule does not seem to play a significant role in producing intrageneric or intraspecific size variation in middle- to large-sized African monkeys; rather, the size variation reflects their phylogenetic relationships or rainfall gradients (as a proxy for resource productivity) in a longitudinal direction (Dunbar, 1990; Turner et al., 1997; Cardini et al., 2007; Jolly, 2012; Cardini et al., 2013).

In contrast, size variation in macaques largely reflects latitudinal climatic gradients, which is peculiar among middle- to large-sized Cercopithecine monkeys; this distinction is attributable to the wider latitudinal distribution of the macaques. Nevertheless, the relative contribution of latitudinal climatic gradients as well as other factors, including differences in sex, species group, and habitat use type, is different among the four species groups. Size variation largely reflects latitudinal climatic gradients in the fascicularis and sinica groups, indicating that animals are larger in colder environments. This finding is in accordance with previous studies (Fooden, 1988, 2006) and is reasonably explained by Bergmann's rule. In contrast, latitudinal climatic gradients have less of an effect on body size in the silenus group (Albrecht, 1980), probably because of its restricted distribution in tropical zones; rather, body size variation reflects differences in habitat use type, as demonstrated by the fact that the terrestrial M. nemestrina is larger than the arboreal M. leonina (Fooden, 1975, 1982). In addition, size variation in the sylvanus group is probably influenced by other factors, 
including sex, rather than latitudinal climatic gradients, as these animals inhabit restricted temperate regions. These findings suggest that the silenus and sylvanus groups are primarily under the control of climate-unrelated pressures, and that the fascicularis and sinica groups are under strong pressures from climatic conditions along a latitudinal gradient, which significantly amplifies body size variations.

Size variation was strongly correlated with facial elongation across macaques; as size increases, a rounded face becomes more elongated. This scaling pattern is probably conserved in the tribe Papionini because a similar pattern was observed in other clades of this tribe, including the genus Papio (Leigh, 2006), large-bodied papionins (Frost et al., 2003), and the entire Papionini tribe (Collard and O'Higgins, 2001; Singleton, 2002; Leigh et al., 2003; Gilbert and Grine, 2010). This common allometric pattern is largely explained by truncation or extension of a common ontogenetic trajectory (O'Higgins and Collard, 2002; Leigh et al., 2003; Leigh, 2006), suggesting that variation in facial elongation of macaques is largely a passive consequence of body size modifications along a common allometry. Thus, facial elongation indirectly reflects various factors influencing body size.

Although differences in the factors influencing body size variation change the amount of shape variation, namely facial elongation, along an allometric trajectory, they cannot be the direct cause of changing the nature (i.e., slope and elevation) of the common allometric pattern. The nature of the common allometric pattern is phylogenetically conserved because 
the slope of the scaling relationship is often homogeneous in papionins, even at the intrageneric level, despite significant body size differences (Singleton, 2002). Nevertheless, some allometric (including ontogenetic) studies have detected the dissociation of common allometric trajectories, including differences in slope and/or elevation that sometimes produce curvilinearity, among papionin genera (Collard and O'Higgins, 2001; Singleton, 2002, 2004, 2005) and even within the genus Papio (Leigh, 2006). These findings suggest that facial elongation in some taxa is not completely explained by the simple extension or truncation of the ancestral ontogenetic trajectory. Such allometric dissociations may be a consequence of functional and adaptive modifications, possibly reflecting dietary differences or sexual selection for increasing canine height and larger gape (Singleton, 2005; Leigh, 2006).

Our analyses revealed a dissociation of the common allometric pattern within the genus Macaca. The slopes of the allometric lines of the fascicularis and sinica groups appeared to be lower than those of the silenus and sylvanus groups. The analysis comparing slopes and elevations among species suggested that the lower slope of the sinica group can be attributed to almost parallel shifts in the allometric lines between tropical and subtropical/temperate species, although M. assamensis does not follow this pattern. The deviation pattern of $M$. sinica was similar to another tropical species, $M$. radiata, and definitely contributed to the lower slope of the sinica group, but it was not tested because of the non-significant regression of $M$. sinica. The lower slope of the fascicularis group was probably caused not only by the 
parallel shifts but also by the decreased slopes in M. fuscata and M. mulatta, which occupy the most widespread range consisting of the coldest climatic conditions. Parallel shifts in the allometric lines, i.e., higher elevations for the tropical zone than the subtropical/temperate zone, were also observed in the entire sample and between the silenus and sylvanus groups. A similar pattern, namely an allometric dissociation among several macaque species, has been reported in previous studies (Fooden, 1988; Mouri, 1996; Rook and O'Higgins, 2005; Fooden, 2006; Singleton, 2012). Our findings suggest that allometric changes have occurred several times in Macaca, including the elevation differences between the species groups, the elevation differences among species within each of the fascicularis and sinica species groups, the decreased slopes in M. mulatta and M. fuscata, and the possible increased slope in $M$. assamensis, M. thibetana, and M. nemestrina. Notably, many allometric changes except for the latter result in the similar situation that the face is more rounded in colder climatic zones and/or larger-bodied animals (thus reflecting colder environments under the effect of Bergmann's rule) than predicted from the overarching allometric pattern. This strongly suggests the influence of climate-related factors either directly or indirectly, which is a pressure favoring a more rounded face in colder environments or a more elongated face in warmer environments.

Specification of climate-related factors affecting the allometric changes in macaques is pending, but three possible candidates can be proposed. One is the effect of Allen's rule, 
which predicts that shorter appendages reduce body heat loss in colder conditions. Treating a face as an appendage, there may be selection pressure that favors a more rounded face with a shorter muzzle in colder conditions. Although the effect of Allen's rule on facial morphology has been rejected in human experimental studies (Steegmann, 1970, 1972), the possibility remains that animals naturally possessing a relatively long muzzle, such as macaques, follow this rule (as in the arctic fox; Prestrud, 1991). Further experimental and theoretical studies are required to verify this supposition. The other two possible factors are indirectly related to climatic conditions. One is the functional adaptation that is related to dietary differences along a latitudinal gradient. A non-tropical seasonal condition reduces annual fruit productivity (Hanya et al., 2013); therefore, some species in this zone eat larger amounts of leaves instead of mature fruit as compared with those in a tropical zone (e.g., Goldstein and Richard, 1989; Ahsan, 1994; Zhou et al., 2011). If the leaves they eat require larger biting force than fruits, it is reasonable to consider that subtropical/temperate species are under selection pressure to have a more rounded face with a shorter muzzle (Singleton, 2005). In addition, intraspecific dietary variations, i.e., relatively larger amounts of leaves and/or barks in colder environments, have also been reported in M. mulatta (Goldstein and Richard, 1989) and M. fuscata (Tsuji, 2010), which can explain their decreased slopes considering that a shorter face probably permits larger bite force (Singleton, 2005). The other possible factor is sexual selection related to differences in reproductive seasonality. Reproductive seasonality is generally weak 
in a tropical zone compared with that in a subtropical/temperate zone, although with some exceptions (Thierry et al., 2000). Weak seasonality means that females in estrus are observed throughout the year, and therefore the number of estrus females at a given time could be limited when compared with species with estrus females that are seasonally constrained within a certain period. Limitations on estrus females may enhance male-male competition, thus causing selection pressure for a more elongated face that allows the males to possess longer canines (Mouri, 1996). Tropical macaque species tend to have relatively longer male canines than do subtropical/temperate species (Plavcan, 1990; Ito, personal observation). Thus, each or a combination of these selection pressures may have caused the allometric dissociation in macaques, as suggested in previous papionin studies (Singleton, 2005; Leigh, 2006). In contrast to the findings for other papionin taxa, these possible factors may be significantly related to latitudinal environmental differences in macaques.

All allometric changes found in this study cannot be explained by the climate-related factors. M. assamensis, despite living in non-tropical regions, shares allometric elevation with tropical species, which means possessing a relatively elongated face. The possible increased slope in M. assamensis, M. thibetana, and M. nemestrina also needs explanations. It may be that the male-male competition was particularly and exceptionally enhanced in these species when compared with their relatives in the same climatic zone, favoring a longer face (see above). Whether it changes slope and/or elevation possibly depends on the strength of other 
selection pressures and on the percentage of sex difference in the total intraspecific body size variation. Furthermore, the fact that regression was insignificant in $M$. sinica would be noteworthy. Although it may be caused just by the limited sample size, it possibly reflects the wide intraspecific shape diversity considering the small adult size range. However, these interpretations lack statistical support or evidence and are pure suppositions.

Much of the non-allometric (and sex-adjusted) shape variation reflected phylogenetic (among species group) differences, whereas some reflected dietary differences. An anteroposteriorly shorter and vertically higher face observed in the hard-food eaters such as $M$. fuscata, M. thibetana, and M. sylvanus is probably advantageous for producing a greater occlusal bite force at the anterior dentition (Singleton, 2004; Koyabu and Endo, 2009) and is desirable for dissipating larger occlusal loads (Antón, 1996). However, it is not conclusive whether this feature solely reflects a dietary adaptation or is a consequence of other climate-related factors (as mentioned above) because dietary differences are highly correlated with climatic conditions (Tsuji et al., 2013). In any case, the three species classified into different species groups may have independently acquired this feature as an adaptation to severe conditions in high-latitude regions, resulting in convergent evolution. In contrast, we showed that some localized shape components often observed in the zygomatic and muzzle regions provide well-conserved phylogenetic information that distinguishes the four species groups. This finding suggests that localized shape components are less affected by latitudinal 
environmental differences, and therefore are useful for taxonomic (species group) identification of fossil specimens.

The species group identification of fossil macaques is intriguing in terms of understanding their paleobiogeography and adaptation to varied climates (Delson, 1977; Jablonski and Pan, 1988), but our analyses suggest that the phylogenetic information on overall facial configuration, degree of elongation, and prognathism is obscured by convergent evolution and the effect of the common allometric pattern. This suggests that conflicts regarding the taxonomic identification of fossil macaques are possibly due to the overall impression of homoplasy in craniofacial shape, as suggested for African papionins (Collard and O'Higgins, 2001; Leigh, 2007). In particular, the phylogenetic utility of the degree of facial elongation is seriously impaired by allometric dissociation even within a species group, reflecting latitudinal environmental differences. This means that even if the common allometric effect is controlled for, the degree of facial elongation may not reflect phylogenetic relationships among the species groups. Because the wider latitudinal distribution of macaques compared with other non-human primates may enhance the direct and/or indirect effects of climatic environments on craniofacial variations, caution should be exercised when evaluating macaque fossil specimens. Further phylogenetic appraisal is required using the localized shape components observed in zygomatics and muzzles, which are probably less affected by environmental differences. 


\section{ACKNOWLEDGEMENTS}

We thank Terutake Hayashi, Tetsu Hayashi, Linda K. Gordon, Eric Delson, Judith

Chupasko, Lawrence R. Heaney, William Stanley, Tracy Damitz, Frieder Mayer, Saskia

Jancke, Nora Brinkmann, Katrin Krohmann, Richard Kraft, Georges Lenglet, Paula Jenkins, Louise Tomsett, Jiang Xue-Long, Song Li, Vu The Long, Vu Ngoc Than, and Lim Kok Peng Kelvin for their help with data collection. We would like to extend our gratitude to Christopher Ruff, an anonymous associate editor, and two anonymous referees for their constructive comments that greatly improved this paper; to Toshio Mouri, Yuzuru Hamada, and Naoko Egi for their comments on an earlier version of this manuscript; and to Chris Klingenberg and Wataru Yano for their supportive comments on geometric morphometric analysis. This study was financially supported in part by the ITP-HOPE and AS-HOPE Programs from JSPS (to T. I.), Grant-in-Aid for JSPS Fellows (to T. I.), Grant-in-Aid for Challenging Exploratory Research (to T. N.), and the Global COE Program from MEXT (Grant A06 to Kyoto University). 


\section{LITERATURE CITED}

Ahsan MF. 1994. Feeding ecology of the primates of Bangladesh. In: Thierry B, Anderson JR, Roeder JJ, and Herrenschmidt N, editors. Current primatology Volume 1 Ecology and evolution. Strasbourg: Universite Louis Pasteur. p 79-86.

Albrecht GH. 1978. The craniofacial morphology of the Sulawesi macaques: Multivariate approaches to biological problems. In: Szalay FS, editor. Contrib Primatol. Basal: S. Karger. p 1-151.

Albrecht GH. 1980. Latitudinal, taxonomic, sexual, and insular determinants of size variation in pigtail macaques, Macaca nemestrina. Int J Primatol 1(2):141-152.

Antón SC. 1996. Cranial adaptation to a high attrition diet in Japanese macaques. Int J Primatol 17(3):401-427.

Bookstein FL. 1989. Principal warps: Thin-plate splines and the decomposition of deformations. ITPAM 11(6):567-585.

Cardini A, Dunn J, O'Higgins P, and Elton S. 2013. Clines in Africa: does size vary in the same way among widespread sub-Saharan monkeys? J Biogeogr 40(2):370-381.

Cardini A, and Elton S. 2008. Does the skull carry a phylogenetic signal? Evolution and modularity in the guenons. Biol J Linn Soc Lond 93:813-834.

Cardini A, Jansson A-U, and Elton S. 2007. A geometric morphometric approach to the study of ecogeographical and clinical variation in vervet monkeys. $\mathrm{J}$ Biogeogr 
$34: 1663-1678$.

Collard M, and O'Higgins P. 2001. Ontogeny and homoplasy in the papionin monkey face. Evol Dev 3:322-331.

Delson E. 1977. Vertebrate paleontology, especially of nonhuman primates, in China. In: Howells WW, and Tsuchitani PJ, editors. Paleoanthropology in the People's Republic of China. Washington, D.C.: National Academy of Science. p 40-65.

Delson E. 1980. Fossil macaques, phyletic relationships and a scenario of deployment. In: Lindburg DG, editor. The macaques: Studies in ecology, behavior and evolution. New York: Nostrand-Reinhold. p 10-30.

Delson E, Terranova CJ, Jungers WL, Sargis EJ, Jablonski NG, and Dechow PC. 2000. Body mass in Cercopithecidae (Primates, Mammalia): estimation and scaling in extinct and extant taxa. Anthropol Pap Am Mus Nat Hist(83):1-159.

Drake AG, and Klingenberg CP. 2008. The pace of morphological change: historical transformation of skull shape in St Bernard dogs. Proc R Soc B-Biol Sci 275(1630):71-76.

Dunbar RIM. 1990. Environmental determinants of intraspecific variation in body-weight in baboons (Papio spp). J Zool 220:157-169.

Fernandez-Duque E. 2011. Rensch's rule, Bergmann's effect and adult sexual dimorphism in wild monogamous Owl monkeys (Aotus azarai) of Argentina. Am J Phys Anthropol 
$146(1): 38-48$.

Fleagle JG. 1999. Primate adaptation and evolution, 2nd edition. New York: Academic Press.

Fooden J. 1969. Taxonomy and evolution of the monkeys of Celebes. Bibliotheca Primatol $10: 1-148$

Fooden J. 1975. Taxonomy and evolution of liontail and pigtail macaques. Fieldiana Zool $67: 1-169$.

Fooden J. 1976. Provisional classification and key to living species of macaques (Primates: Macaca). Folia Primatol (Basel) 25:225-236.

Fooden J. 1982. Ecogeographic segregation of macaque species. Primates 23(4):574-579.

Fooden J. 1985. Taxonomy and evolution of the sinica group of macaques: 5. Overview of natural history. Fieldiana Zool 29:1-22.

Fooden J. 1988. Taxonomy and Evolution of the sinica group of macaques: 6. Interspecific comparisons and synthesis. Fieldiana Zool 45:1-44.

Fooden J. 1990. The bear macaques, Macaca arctoides: a systematic review. J Hum Evol 19:607-686.

Fooden J. 2006. Comparative review of fascicularis-group species of macaques (Primates: Macaca). Fieldiana Zool 107(16):1-44.

Fooden J. 2007. Systematic review of the Barbary macaque, Macaca sylvanus (Linneaus, 1758). Fieldiana Zool 113(63):1-58. 
Fooden J, and Albrecht GH. 1993. Latitudinal and insular variation of skull size in crab-eating macaques (primates, Cercopithecidae: Macaca fascicularis). Am J Phys Anthropol $92: 521-538$.

Fooden J, and Wu HY. 2001. Systematic review of the Taiwanese macaque, Macaca cyclopis Swinhoe, 1863. Fieldiana Zool 98(30):1-70.

Frost SR, Marcus LF, Bookstein FL, Reddy DP, and Delson E. 2003. Cranial allometry, phylogeography, and systematics of large-bodied papionins (primates: Cercopithecinae) inferred from geometric morphometric analysis of landmark data. Anat Rec A Discov Mol Cell Evol Biol 275A:1048-1072.

Gilbert CC, and Grine FE. 2010. Morphometric variation in the papionin muzzle and the biochronology of the South African Plio-Pleistocene karst cave deposits. Am J Phys Anthropol 141:418-429.

Goldstein SJ, and Richard AF. 1989. Ecology of rhesus macaques (Macaca mulatta) in northwest Pakistan. Int J Primatol 10(6):531-567.

Gower JC. 1971. A general coefficient of similarity and some of its properties. Biometrics:857-871.

Hamada Y, Watanabe T, and Iwamoto M. 1996. Morphological variations among local populations of Japanese macaque (Macaca fuscata). In: Shotake T, and Wada K, editors. Variations in the Asian macaques. Tokyo: Tokyo University Press. p 97-115. 
Hanya G, Tsuji Y, and Grueter CC. 2013. Fruiting and flushing phenology in Asian tropical and temperate forests: implications for primate ecology. Primates:1-10.

Harcourt AH, and Schreier BM. 2009. Diversity, body mass, and latitudinal gradients in primates. Int J Primatol 30(2):283-300.

Hijmans RJ, Cameron SE, Parra JL, Jones PG, and Jarvis A. 2005. Very high resolution interpolated climate surfaces for global land areas. IJCli 25(15):1965-1978.

Ito T, Nishimura T, and Takai M. 2011. Allometry and interspecific differences in the facial cranium of two closely related macaque species. Anat Res Int 849751.

Iwamoto M. 1975. On a skull of a fossil macaque from the Shikimizu limestone quarry in the Shikoku district, Japan. Primates 16(1):83-94.

Jablonski N. 2002. Fossil old world monkeys: the late Neogene radiation. In: Hartwig WC, editor. The primate fossil record. Cambridge: Cambridge University Press. p 255-299.

Jablonski NG, and Pan Y. 1988. The evolution and palaeobiogeography of monkeys in China. In: Whyte P, Aigner J, Jablonski NG, Taylor G, Walker D, and Wang PX, editors. The palaeoenvironment of East Asia from the Mid-Tertiary. Hong Kong: Centre of Asian Studies. p 849-867.

Jolly CJ. 2012. Rainfall is not a genus-wide predictor of mean body mass in baboon populations. J Zool 286(3):185-193.

Kamilar JM, Muldoon KM, Lehman SM, and Herrera JP. 2012. Testing Bergmann's rule and 
the resource seasonality hypothesis in Malagasy primates using GIS-based climate data. Am J Phys Anthropol 147(3):401-408.

Klingenberg CR. 2011. MorphoJ: an integrated software package for geometric morphometrics. Mol Ecol Res 11(2):353-357.

Koyabu DB, and Endo H. 2009. Craniofacial variation and dietary adaptations of African colobines. J Hum Evol 56:525-536.

Lahann P, Schmid J, and Ganzhorn JU. 2006. Geographic variation in populations of Microcebus murinus in Madagascar: Resource seasonality or Bergmann's rule? Int J Primatol 27(4):983-999.

Leigh SR. 2006. Cranial ontogeny of Papio baboons (Papio hamadryas). Am J Phys Anthropol 130:71-84.

Leigh SR. 2007. Homoplasy and the evolution of ontogeny in papionin primates. J Hum Evol 52(5):536-558.

Leigh SR, Shah NF, and Buchanan LS. 2003. Ontogeny and phylogeny in papionin primates. J Hum Evol 45:285-316.

Li J, Han K, Xing J, Kim HS, Rogers J, Ryder OA, Disotell T, Yue B, and Batzer MA. 2009. Phylogeny of the macaques (Cercopithecidae: Macaca) based on Alu elements. Gene 448:242-249.

Mantel N. 1967. The detection of disease clustering and a generalized regression approach. 
Cancer Res 27(2 Part 1):209-220.

Mitteroecker P, and Gunz P. 2009. Advances in geometric morphometrics. Evol Biol $36(2): 235-247$

Monteiro LR. 1999. Multivariate regression models and geometric morphometrics: the search for causal factors in the analysis of shape. Syst Biol 48(1):192-199.

Morales JC, and Melnick DJ. 1998. Phylogenetic relationships of the macaques (Cercopithecidae: $M a c a c a$ ), as revealed by high resolution restriction site mapping of mitochondrial ribosomal genes. J Hum Evol 34:1-23.

Mouri T. 1996. Multivariate cranial ontogenetic allometries in Crab-eating Rhesus and Japanese macaques. Anthropol Sci 104(4):281-303.

O'Higgins P, and Collard M. 2002. Sexual dimorphism and facial growth in papionin monkeys. J Zool 257(2):255-272.

O'Higgins P, and Jones N. 1998. Facial growth in Cercocebus torquatus: an application of three-dimensional geometric morphometric techniques to the study of morphological variation. J Anat 193:251-272.

O'Higgins P, and Jones N. 2006. Tools for statistical shape analysis. Hull York Medical School; http://sites.google.com/site/hymsfme/resources.

Pan R, Jablonski NG, Oxnard C, and Freedman L. 1998. Morphometric analysis of Macaca arctoides and $M$. thibetana in relation to other macaque species. Primates 
39(4):519-537.

Pan R, and Oxnard CE. 2000. Craniodental variation of macaques (Macaca): size, function and phylogeny. Zool Res 21(4):308-322.

Pan R, and Oxnard CE. 2001. Radiation and evolution of three macaque species, Macaca fascicularis, M. radiata and $M$. sinica, as related to geographic changes in the Pleistocene of Southeast Asia. In: Metcalfe I, Smith JMB, Morwood M, and Hewsion $\mathrm{K}$, editors. Faunal and floral migrations and evolution in SE Asia-Australasia. Netherlands: Swets and Zeitlinger. p 337-355.

Pan R, and Oxnard CE. 2002. Craniodental variation among Macaques (Macaca), nonhuman primates. BMC Evol Biol 2:1-12.

Pan R, Wei F, and Li M. 2003. Craniofacial variation of the Chinese macaques explored with morphologika. J Morphol 256:342-348.

Plavcan JM. 1990. Sexual dimorphism in the dentition of extant anthropoid primates. $\mathrm{PhD}$ Thesis. North Carolina: Duke University.

Prestrud P. 1991. Adaptations by the arctic fox (Alopex lagopus) to the polar winter. Arctic:132-138.

Ravosa MJ. 1998. Cranial allometry and geographic variation in slow lorises (Nycticebus). Am J Primatol 45:225-243.

Rohlf FJ. 2005. NTSYSpc, Numerican taxonomy system, version 2.21a. Exerter Software. 
New York.

Rohlf FJ, and Slice D. 1990. Extensions of the procrustes method for the optimal superimposition of landmarks. Syst Zool 39(1):40-59.

Rook L, and O'Higgins P. 2005. A comparative study of adult facial morphology and its ontogeny in the fossil macaque Macaca majori from Capo Figari, Sardinia, Italy. Folia Primatol (Basel) 76:151-171.

Schillaci M, Meijaard E, and Clark T. 2009. The effect of island area on body size in a primate species from the Sunda shelf island. J Biogeogr 36:362-371.

Schlosser M. 1924. Fossil primates from China. Palaeontologia Sinica, Series C 1(2):1-16.

Singleton M. 2002. Patterns of cranial shape variation in the Papionini (Primates: Cercopithecinae). J Hum Evol 42:547-578.

Singleton M. 2004. Geometric morphometric analysis of functional divergence in mangabey facial form. J Anthropol Sci 82:29-46.

Singleton M. 2005. Functional shape variation in the Cercopithecine masticatory complex. In: Slice DE, editor. Modern morphometrics in Physical Anthropology. New York: Kluwer Academic/Plenum Publishers. p 319-348.

Singleton M. 2012. Postnatal cranial development in papionin primates: An alternative model for hominin evolutionary development. Evol Biol 39(4):499-520.

Slice DE. 1999. Morpheus et al. (beta version). Department of ecology and evolution, State 
University. New York, Stony Brook.

Smouse PE, Long JC, and Sokal RR. 1986. Multiple regression and correlation extensions of the Mantel test of matrix correspondence. Syst Zool 35(4):627-632.

Steegmann AT. 1970. Cold adaptation and the human face. Am J Phys Anthropol 32:243-250.

Steegmann AT. 1972. Cold response, body form, and craniofacial shape in two racial groups of Hawaii. Am J Phys Anthropol 37(2):193-221.

Thierry B, Iwaniuk AN, and Pellis SM. 2000. The influence of phylogeny on the social behavior of macaques (Primates: Cercopithecidae, genus Macaca). Ethology 106:713-728.

Tosi AJ, Morales JC, and Melnick DJ. 2000. Comparison of Y chromosome and mtDNA phylogenies leads to unique inferences of macaque evolutionary history. Mol Phylogen Evol 17:133-144.

Tosi AJ, Morales JC, and Melnick DJ. 2003. Paternal, maternal, and biparental molecular markers provide unique windows onto the evolutionary history of macaque monkeys.

Evolution 57:1419-1435.

Tsuji Y. 2010. Regional, temporal, and interindividual variation in the feeding ecology of Japanese macaques. The Japanese macaques: Springer. p 99-127.

Tsuji Y, Hanya G, and Grueter CC. 2013. Feeding strategies of primates in temperate and alpine forests: comparison of Asian macaques and colobines. Primates 54(3):201-215. 
Turner TR, Anapol F, and Jolly CJ. 1997. Growth, development, and sexual dimorphism in vervet monkeys (Cercopithecus aethiops) at four sites in Kenya. Am J Phys Anthropol 103(1):19-35

Zelditch ML, Swiderski DL, and Sheets HD. 2012. Geometric morphometrics for biologists: a primer: Academic Press.

Zhou QH, Wei H, Huang ZH, and Huang CM. 2011. Diet of the Assamese macaque Macaca assamensis in limestone habitats of Nonggang, China. Curr Zool 57(1):18-25. 


\section{FIGURE LEGENDS}

Fig. 1 Cladogram of macaques: phylogenetic relationship among the four species groups

(Table 1). A: Modified after Delson (1980), which is based on genitalia, cranial morphology, biogeography, and fossil records (see also Fooden, 1976). B: Modified after Tosi et al. (2003), which was based on mitochondrial DNA (see also Morales and Melnick, 1998). This resolved the phylogenetic relationship among the four species groups but the phylogenetic position of M. arctoides was different from the others. C: Modified after Tosi et al. (2003), which was based on Y-chromosome DNA. This supports the monophyly of each of the four species groups but cannot resolve the intergroup relationships. D: Modified after Li et al. (2009), which was based on Alu elements. This provides strong statistical support for the monophyly of each of the four species groups and resolved the intergroup phylogenetic relationships.

Fig. 2 Geographic distribution of local populations of macaques used in this study (Table 2). Dashed lines indicate border between populations belonging to same species. A: the fascicularis group. Circle, M. fascicularis; triangle, M. mulatta; cross, M. cyclopis; square, M. fuscata. B: the sinica group. Circle, M. arctoides; triangle, M. assamensis; square, M. thibetana; cross, M. radiata; star, M. sinica. C: the silenus group. Circle, M. nemestrina; triangle, M. leonina. D: the sylvanus group. Circle, M. sylvanus. 
Fig. 3 Landmarks on facial regions used in this study. A: Lateral view. B: Frontal view.

\author{
C: Inferior view.
}

Fig. 4 A: Relationship between the natural logarithms of species average (split sex) neurocranium centroid size (CS) and species average (split sex) body mass. B: The estimation of individual's body size. Both sexes are indicated by the same symbol; for all species, males are larger than females.

Fig. 5 Allometric pattern of craniofacial shape across macaques. A: Shape variations along the axis of the shape score. Shape changes are shown as the smooth surface rendering of polygons, Cartesian transformation grids, and wireframes. The deformation of Cartesian transformation grids indicates transformation from the grand mean to positive and negative extremes. The wireframe of the solid line and right images represent the positive extreme $(+1.0)$, and that of the dashed line and left images represent the negative extreme $(-1.0)$. Arrows indicate the relative size of the upper face against the lower face and the relative elongation of the muzzle and the facial profile line. B: Relationship between body size surrogates and shape scores. Symbols represent climatic zones. Solid line represents a regression line for subtropical/temperate animals $\left(y=0.074 x-0.680, R^{2}=0.57, p<0.001\right)$; dashed line represents a regression line for tropical animals $\left(y=0.078 x-0.671, R^{2}=0.54, p\right.$ 
$<0.001)$. C: Same as B, but symbols represent species groups. Solid line represents a regression line for the fascicularis group $\left(\mathrm{y}=0.043 \mathrm{x}-0.340, \mathrm{R}^{2}=0.32, \mathrm{p}<0.001\right)$; dashed line represents a regression line for the sinica group $\left(\mathrm{y}=0.061 \mathrm{x}-0.545, \mathrm{R}^{2}=0.54, \mathrm{p}<\right.$ 0.001); dotted line represents a regression line for the silenus group $\left(\mathrm{y}=0.087 \mathrm{x}-0.752, \mathrm{R}^{2}=\right.$ $0.51, \mathrm{p}<0.001)$; dot-dashed line represents a regression line for the sylvanus group $(\mathrm{y}=$ $\left.0.077 \mathrm{x}-0.725, \mathrm{R}^{2}=0.34, \mathrm{p}=0.058\right)$. D-F: Same as $\mathrm{B}$, but for the fascicularis, sinica, and silenus groups, respectively (Table 5). Symbols represent species.

Fig. 6 Shape changes associated with species group differences. A: Scatterplot of CV1 against CV2. B: Shape changes along the axis of CV1. Arrows indicate the relative height and width of the upper muzzle. C: Shape changes along the axis of CV2. Arrows indicate the convexity (and concavity) of the nasal profile line and the relative width of the zygomatic. D: Scatterplot of CV3 against CV2. E: Shape changes along the axis of CV3. Arrows indicate the relative position of the zygomatic. The shapes of positive $(+4.0$, but +8.0 for $\mathrm{CV} 3)$ and negative $(-4.0)$ extremes are represented for each axis.

Fig. 7 Shape changes associated with dietary difference. A: Histogram of CV1 scores. B: Shape changes along the axis of CV1. Arrows indicate relative height, width, and length of the face. 
Table 1. Ecogeographical and phylogenetic categories.

\begin{tabular}{|c|c|c|c|c|}
\hline Species & Climatic zones & Dietary habits & $\begin{array}{l}\text { Habitat use } \\
\text { types }\end{array}$ & Species groups \\
\hline M. fascicularis & tropical zone & $\begin{array}{l}\text { non-hard food } \\
\text { eaters }\end{array}$ & arboreal & $\begin{array}{l}\text { the fascicularis } \\
\text { group }\end{array}$ \\
\hline M. mulatta & $\begin{array}{l}\text { subtropical/temp } \\
\text { erate zone }\end{array}$ & $\begin{array}{l}\text { non-hard food } \\
\text { eaters }\end{array}$ & $\begin{array}{l}\text { intermediate/unc } \\
\text { ertain }\end{array}$ & $\begin{array}{l}\text { the fascicularis } \\
\text { group }\end{array}$ \\
\hline M. cyclopis & $\begin{array}{l}\text { subtropical/temp } \\
\text { erate zone }\end{array}$ & $\begin{array}{l}\text { non-hard food } \\
\text { eaters }\end{array}$ & $\begin{array}{l}\text { intermediate/unc } \\
\text { ertain }\end{array}$ & $\begin{array}{l}\text { the fascicularis } \\
\text { group }\end{array}$ \\
\hline M. fuscata & $\begin{array}{l}\text { subtropical/temp } \\
\text { erate zone }\end{array}$ & $\begin{array}{l}\text { hard food } \\
\text { eaters }\end{array}$ & $\begin{array}{l}\text { intermediate/unc } \\
\text { ertain }\end{array}$ & $\begin{array}{l}\text { the fascicularis } \\
\text { group }\end{array}$ \\
\hline M. sinica & tropical zone & $\begin{array}{l}\text { non-hard food } \\
\text { eaters }\end{array}$ & $\begin{array}{l}\text { intermediate/unc } \\
\text { ertain }\end{array}$ & the sinica group \\
\hline M. radiata & tropical zone & $\begin{array}{l}\text { non-hard food } \\
\text { eaters }\end{array}$ & $\begin{array}{l}\text { intermediate/unc } \\
\text { ertain }\end{array}$ & the sinica group \\
\hline M. arctoides & $\begin{array}{l}\text { subtropical/temp } \\
\text { erate zone }\end{array}$ & $\begin{array}{l}\text { non-hard food } \\
\text { eaters }\end{array}$ & terrestrial & the sinica group \\
\hline M. assamensis & $\begin{array}{l}\text { subtropical/temp } \\
\text { erate zone }\end{array}$ & $\begin{array}{l}\text { non-hard food } \\
\text { eaters }\end{array}$ & arboreal & the sinica group \\
\hline M. thibetana & $\begin{array}{l}\text { subtropical/temp } \\
\text { erate zone }\end{array}$ & $\begin{array}{l}\text { hard food } \\
\text { eaters }\end{array}$ & $\begin{array}{l}\text { intermediate/unc } \\
\text { ertain }\end{array}$ & the sinica group \\
\hline M. nemestrina & tropical zone & $\begin{array}{l}\text { non-hard food } \\
\text { eaters }\end{array}$ & terrestrial & the silenus group \\
\hline M. leonina & tropical zone & $\begin{array}{l}\text { non-hard food } \\
\text { eaters }\end{array}$ & arboreal & the silenus group \\
\hline M. sylvanus & $\begin{array}{l}\text { subtropical/temp } \\
\text { erate zone }\end{array}$ & $\begin{array}{l}\text { hard food } \\
\text { eaters }\end{array}$ & terrestrial & $\begin{array}{l}\text { the sylvanus } \\
\text { group }\end{array}$ \\
\hline
\end{tabular}

Details are described in the text. 
Table 2. Samples used in this study.

\begin{tabular}{|c|c|c|c|c|c|c|c|c|}
\hline \multirow[t]{2}{*}{ Species } & \multirow{2}{*}{$\begin{array}{l}\text { Population } \\
\text { (Sampling } \\
\text { unit) }\end{array}$} & \multirow[t]{2}{*}{ Region } & \multicolumn{5}{|c|}{ Sample size* } & \multirow{2}{*}{$\begin{array}{l}\text { The } \\
\text { number of } \\
\text { geographic } \\
\text { points }\end{array}$} \\
\hline & & & $\mathrm{F}$ & & M & & Total & \\
\hline \multirow[t]{3}{*}{ M. fascicularis } & $\begin{array}{l}\text { Sunda } \\
\text { Islands } \\
\text { fascicularis }\end{array}$ & Sunda islands ${ }^{1}$ & 20 & & 20 & & 40 & 20 \\
\hline & $\begin{array}{l}\text { Indochinese } \\
\text { fascicularis }\end{array}$ & $\begin{array}{l}\text { Southern } \\
\text { Indochina }\end{array}$ & 20 & & 20 & & 40 & 25 \\
\hline & $\begin{array}{l}\text { Philippine } \\
\text { fascicularis }\end{array}$ & $\begin{array}{l}\text { Philippine } \\
\text { islands }^{2}\end{array}$ & 20 & & 20 & & 40 & 14 \\
\hline \multirow[t]{3}{*}{ M. mulatta } & $\begin{array}{l}\text { Indochinese } \\
\text { mulatta }\end{array}$ & $\begin{array}{l}\text { Northern } \\
\text { Indochina and } \\
\text { northeastern } \\
\text { India } \\
\text { (Manipur) }\end{array}$ & 20 & & 19 & (1) & 39 & 15 \\
\hline & $\begin{array}{l}\text { South } \\
\text { Asian } \\
\text { mulatta }\end{array}$ & $\begin{array}{l}\text { Northern India } \\
\text { and Pakistan }\end{array}$ & 12 & (1) & 19 & (1) & 31 & 14 \\
\hline & $\begin{array}{l}\text { Chinese } \\
\text { mulatta }\end{array}$ & $\begin{array}{l}\text { Southern and } \\
\text { eastern China }\end{array}$ & 16 & (1) & 15 & (1) & 31 & 5 \\
\hline M. cyclopis & cyclopis & Taiwan & 11 & & 12 & & 23 & 1 \\
\hline \multirow[t]{2}{*}{ M. fuscata } & $\begin{array}{l}\text { fuscata } \\
\text { yakui }\end{array}$ & Yaku island & 20 & & 20 & & 40 & 1 \\
\hline & $\begin{array}{l}\text { fuscata } \\
\text { fuscata }\end{array}$ & $\begin{array}{l}\text { Japan } \\
\text { excluding } \\
\text { Yaku island }\end{array}$ & 20 & & 20 & & 40 & 13 \\
\hline M. sinica & sinica & Ceylon island & 6 & & 12 & (1) & 18 & 6 \\
\hline M. radiata & radiata & Southern India & 7 & (1) & 10 & & 17 & 4 \\
\hline M. arctoides & arctoides & $\begin{array}{l}\text { Northeastern } \\
\text { India, southern } \\
\text { China, and } \\
\text { Indochina }\end{array}$ & 12 & (3) & 20 & (1) & 32 & 13 \\
\hline M. assamensis & $\begin{array}{l}\text { assamensis } \\
\text { pelops }\end{array}$ & $\begin{array}{l}\text { Nepal and } \\
\text { northeastern } \\
\text { India }\end{array}$ & 5 & & 10 & (1) & 15 & 3 \\
\hline
\end{tabular}


(Arunachal

Pradesh)

assamensis Southern

11

20

(1) 31

14

assamensis China,

northern

Indochina, and

northeastern

India

(Nagaland)

M. thibetana

thibetana

Southern and

4

eastern China

M. nemestrina

Borneo

Borneo

7

nemestrina

Western

Sumatra and

12

(2) 20

32

13

nemestrina

southern

Malay

peninsula

M. leonina

leonina

Northeastern

14

(3) 20

(1) 34

12

India, Southern

China, and

northern

Indochina

M. sylvanus

sylvanus

Morocco and 6

(2) 5

112

Gibraltar

The specimens are housed at the Hakusan Nature Conservation Center, Hakusan, Japan; the Tochigi Prefectural Museum, Utsunomiya, Japan; the Primate Research Institute of Kyoto University, Inuyama, Japan; the Kunming Institute of Zoology, Kunming, China; the Zoological Museum of National University of Hanoi, Hanoi, Vietnam; the Raffles Museum of Biodiversity Research, Singapore; the Museum für Naturkunde of Humboldt University, Berlin, Germany; the Naturmuseum Senckenberg, Frankfurt, Germany; the Zoologische Staatssammlung München, Munich, Germany; the Natural History Museum, London, UK; the National Museum of Natural History, Washington DC, USA; the American Museum of Natural History, New York, NY, USA; the Museum of Comparative Zoology of Harvard University, Cambridge, MA, USA; and the Field Museum of Natural History, Chicago, IL, USA. *Number in parentheses indicates the number of specimens lacking geographic data. ${ }^{1}$ Bali, Borneo, Bunguran, Flores, Java, Lombok, Nias, Simeulue, Sumatra, Sumbawa, and Timor islands. ${ }^{2}$ Distribution region of M. f. philippinensis and contact region between this subspecies and M.f. fascicularis (Fooden 1990b). 
32

33

34

35

36

37

38

39

40

41

42

43

44

45

46

47

48

49

50

51

52

53

54

55

56

57

58

59

60

John Wiley \& Sons, Inc. 
Table 3. Landmarks used in this study.

\begin{tabular}{|c|c|c|}
\hline Region & $\begin{array}{l}\text { Abbrevi } \\
\text { ation }\end{array}$ & Definition \\
\hline \multirow[t]{22}{*}{ Face } & PRS & $\begin{array}{l}\text { Prosthion: antero-inferior point on projection of premaxilla between } \\
\text { central incisors. }{ }^{1}\end{array}$ \\
\hline & IFR & Posterior-most point of incisive foramen. ${ }^{1}$ \\
\hline & MXP & Meeting point of maxilla and palatine along midline. ${ }^{1}$ \\
\hline & PNS & Tip of posterior nasal spine. ${ }^{1}$ \\
\hline & GPF & Most posterior point on the margin of greater palatine foramen. ${ }^{1}$ \\
\hline & NSP & Nasospinale: inferior-most midline point of piriform aperture. ${ }^{1}$ \\
\hline & WPA & Point corresponding to largest width of piriform aperture. ${ }^{1}$ \\
\hline & NPM & Meeting point of nasal and pre-maxilla on margin of piriform aperture. ${ }^{1}$ \\
\hline & RHI & Rhinion: most anterior midline point on nasals. ${ }^{1}$ \\
\hline & NAS & Nasion: midline point on fronto-nasal suture. ${ }^{1}$ \\
\hline & DCR & $\begin{array}{l}\text { Dacryon: most superior point of the lacrimomaxillary suture } \\
\text { (intersection with frontal bone). }{ }^{2}\end{array}$ \\
\hline & IST & $\begin{array}{l}\text { Point on inferior margin of supraorbital torus (superior margin of orbit) } \\
\text { at middle of orbit. }{ }^{3}\end{array}$ \\
\hline & FRO & $\begin{array}{l}\text { Frontomalare orbitale: where frontozygomatic suture crosses inner } \\
\text { orbital rim. }{ }^{1}\end{array}$ \\
\hline & ZMS & $\begin{array}{l}\text { Zygo-max superior: antero-superior point of zygomaticomaxillary } \\
\text { suture taken at orbit rim. }{ }^{1}\end{array}$ \\
\hline & FRT & $\begin{array}{l}\text { Frontomalare temporale: where frontozygomatic suture crosses lateral } \\
\text { edge of zygoma. }{ }^{1}\end{array}$ \\
\hline & ZMI & $\begin{array}{l}\text { Zygo-max inferior: antero-inferior point of zygomaticomaxillary } \\
\text { suture. }{ }^{1}\end{array}$ \\
\hline & CZA & Maximum curvature of anterior upper margin of zygomatic arch. ${ }^{1}$ \\
\hline & PMS & The point where premaxillary suture crosses alveolar marigin. ${ }^{3}$ \\
\hline & MP3 & $\begin{array}{l}\text { Mesial P3: most mesial point on } \mathrm{P}^{3} \text { alveolus, projected labially onto } \\
\text { alveolar margin. }{ }^{1}\end{array}$ \\
\hline & MM1 & $\begin{array}{l}\text { Mesial M1: contact points between } \mathrm{P}^{4} \text { and } \mathrm{M}^{1} \text {, projected labially onto } \\
\text { alveolar margin. }\end{array}$ \\
\hline & MM3 & $\begin{array}{l}\text { Mesial M3: contact points between } \mathrm{M}^{2} \text { and } \mathrm{M}^{3} \text {, projected labially onto } \\
\text { alveolar margin. }\end{array}$ \\
\hline & DM3 & Distal M3: posterior midpoint onto alveolar margin of $\mathrm{M}^{3} .1$ \\
\hline $\begin{array}{l}\mathrm{Face} / \mathrm{Ne} \\
\text { urocrani }\end{array}$ & GLA & $\begin{array}{l}\text { Glabella: most forward projecting midline point of frontals at the level } \\
\text { of the supraorbital ridges. }{ }^{1}\end{array}$ \\
\hline
\end{tabular}


um

\begin{tabular}{|c|c|c|}
\hline \multirow[t]{7}{*}{$\begin{array}{l}\text { Neurocr } \\
\text { anium }\end{array}$} & BRG & $\begin{array}{l}\text { Bregma: junction of coronal and sagittal sutures, on sagittal crest if } \\
\text { necessary. }\end{array}$ \\
\hline & INI & $\begin{array}{l}\text { Inion: most posterior point of cranium, when viewed in the Frankfurt } \\
\text { horizontal, be it on sagittal/nuchal crest or not. }{ }^{3}\end{array}$ \\
\hline & OPS & Opisthion: posterior most point of foramen magnum. ${ }^{3}$ \\
\hline & BAS & Basion: anterior most point of foramen magnum. ${ }^{3}$ \\
\hline & HOR & Hormion: midpoint of the posterosuperior border of the vomer. ${ }^{2}$ \\
\hline & POR & Porion: top of auditory meatus. ${ }^{3}$ \\
\hline & ZAP & $\begin{array}{l}\text { Meeting point of zygomatic arch and alisphenoid on superior } \\
\text { margin of pterygomaxillary fissure. }{ }^{1}\end{array}$ \\
\hline \multirow[t]{3}{*}{ Other } & ZTS & $\begin{array}{l}\text { Zygo-temp superior: superior point of zygomatico-temporal suture on } \\
\text { lateral face of zygomatic arch. }{ }^{3}\end{array}$ \\
\hline & ZTI & $\begin{array}{l}\text { Zygo-temp inferior: inferior point of zygomatico-temporal suture on } \\
\text { lateral face of zygomatic arch. }{ }^{3}\end{array}$ \\
\hline & $\mathrm{ZPT}$ & $\begin{array}{l}\text { Posterior-most point on curvature of anterior margin of zygomatic } \\
\text { process of temporal bone. }{ }^{1}\end{array}$ \\
\hline
\end{tabular}

${ }^{1}$ Cardini et al. (2007), ${ }^{2}$ Cobb and O'Higgins (2007), ${ }^{3}$ Frost et al. (2003). 
Table 4. Multivariate regression of body size surrogate against climate, sex, habitat use type, and species group.

\begin{tabular}{|c|c|c|c|c|c|c|c|c|}
\hline Sample & $\mathrm{R}^{2}$ & $\mathrm{p}$ & $\begin{array}{l}\text { independent } \\
\text { variables }\end{array}$ & $\begin{array}{l}\text { partial } \\
\text { regression } \\
\text { coefficient }\end{array}$ & $\begin{array}{l}\text { Std. } \\
\text { Error }\end{array}$ & t value & $\mathrm{p}$ & $\begin{array}{l}\text { standard } \\
\text { partial } \\
\text { regression } \\
\text { coefficient* }\end{array}$ \\
\hline \multirow[t]{7}{*}{$\begin{array}{l}\text { total } \\
\text { sample }\end{array}$} & \multirow[t]{7}{*}{0.78} & \multirow[t]{7}{*}{$\begin{array}{l}<0 . \\
001\end{array}$} & intercept & 9.99 & 0.056 & 179.6 & $\begin{array}{l}<0 . \\
001\end{array}$ & 0.01 \\
\hline & & & temperature $^{1}$ & -0.01 & 0.000 & -30.4 & $\begin{array}{l}<0 \\
001\end{array}$ & -0.70 \\
\hline & & & male $^{2}$ & 0.37 & 0.021 & 17.9 & $\begin{array}{l}<0 . \\
001\end{array}$ & 0.38 \\
\hline & & & $\begin{array}{l}\text { habitat use } \\
\text { type }\end{array}$ & 0.18 & 0.016 & 11.1 & $\begin{array}{l}<0 \\
001\end{array}$ & 0.26 \\
\hline & & & sinica group $^{3}$ & 0.22 & 0.025 & 8.7 & $\begin{array}{l}<0 \\
001\end{array}$ & 0.19 \\
\hline & & & $\begin{array}{l}\text { silenus } \\
\text { group }^{3}\end{array}$ & 0.31 & 0.033 & 9.2 & $\begin{array}{l}<0 \\
001\end{array}$ & 0.23 \\
\hline & & & $\begin{array}{l}\text { sylvanus } \\
\text { group }^{3}\end{array}$ & -0.21 & 0.082 & -2.5 & $\begin{array}{l}0.0 \\
12\end{array}$ & -0.06 \\
\hline
\end{tabular}

fascicul

aris

$0.81<0$

$<0$.
001

intercept $\quad 10.06$

$\begin{array}{cccc}0.091 & 110.1 & <0 . & 0.00\end{array}$

group

$\begin{array}{lccccc}\text { temperature }^{1} & -0.01 & 0.000 & -21.0 & 001 & \mathbf{- 0 . 7 3} \\ \text { male }^{2} & 0.34 & 0.024 & 14.2 & <0 . & 0.35\end{array}$

habitat use

0.14

$\begin{array}{lll}0.035 & 3.9 & <0 . \\ & & 001\end{array}$

type

0.13

sinica

group

$$
\begin{array}{ll}
0.69 \quad<0 \\
& 001
\end{array}
$$

intercept $\quad 10.47$

$\begin{array}{llll}0.141 & 74.5 & <0 . & 0.02\end{array}$

temperature $^{1} \quad-0.01$

$0.001-13.2 \quad 00$

$<0$.

$-0.73$

male ${ }^{2}$

0.44

$<0$.

habitat use

type

0.14

0.054

8.2

001

0.43

$<0$.

0.22 


\footnotetext{
*The largest contribution is indicated by bold. ${ }^{1}$ The annual mean temperature. ${ }^{2}$ Sex. ${ }^{3}$ Species group. ${ }^{2,3}$ These are nominal and thus coded as dummy variables. One of the dummy variables ("female" for sex and "fascicularis group" for species group) was eliminated from the regression equation because the information of one variable can be readily obtained from that of the other variables (Suits, 1957). The eliminated variable can be regarded as a reference.
} 
Table 5. Scaling pattern for each species.

\begin{tabular}{|c|c|c|c|c|c|c|c|c|}
\hline \multicolumn{5}{|c|}{$\begin{array}{l}\text { Equations for the least-squares regression of } \\
\text { the shape scores on the body size surrogates. }\end{array}$} & \multicolumn{4}{|c|}{ Slope divergences from a general trend. } \\
\hline Species & $\begin{array}{l}\text { Slop } \\
\text { e }\end{array}$ & $\begin{array}{l}\text { Elevatio } \\
\mathrm{n}\end{array}$ & $\mathrm{R}^{2}$ & $\mathrm{p}$ & $\begin{array}{l}\text { Angles between the } \\
\text { slopes for each } \\
\text { species and a general } \\
\text { trend }\end{array}$ & df & $\mathrm{F}$ & $\mathrm{p}$ \\
\hline $\begin{array}{l}\text { M. } \\
\text { fasciculari } \\
S\end{array}$ & 0.081 & -0.688 & $\begin{array}{l}0.4 \\
1\end{array}$ & $\begin{array}{l}<0.00 \\
1\end{array}$ & 0.003 & 1 & 0.058 & 0.810 \\
\hline M. mulatta & 0.052 & -0.491 & $\begin{array}{l}0.4 \\
2\end{array}$ & $\begin{array}{l}<0.00 \\
1\end{array}$ & -0.022 & 1 & 8.008 & 0.005 \\
\hline M. cyclopis & 0.083 & -0.778 & $\begin{array}{l}0.5 \\
4\end{array}$ & $\begin{array}{l}<0.00 \\
1\end{array}$ & 0.009 & 1 & 0.162 & 0.688 \\
\hline M. fuscata & 0.043 & -0.377 & $\begin{array}{l}0.1 \\
8\end{array}$ & $\begin{array}{l}<0.00 \\
1\end{array}$ & -0.032 & 1 & 7.262 & 0.007 \\
\hline M. sinica & 0.009 & -0.102 & $\begin{array}{l}0.0 \\
1\end{array}$ & 0.629 & - & - & - & - \\
\hline$M$. radiata & 0.080 & -0.703 & $\begin{array}{l}0.3 \\
6\end{array}$ & 0.011 & 0.002 & 1 & 0.004 & 0.952 \\
\hline $\begin{array}{l}\text { M. } \\
\text { arctoides }\end{array}$ & 0.072 & -0.667 & $\begin{array}{l}0.5 \\
4\end{array}$ & $\begin{array}{l}<0.00 \\
1\end{array}$ & -0.002 & 1 & 0.014 & 0.905 \\
\hline $\begin{array}{l}\text { M. } \\
\text { assamensis }\end{array}$ & 0.098 & -0.870 & $\begin{array}{l}0.6 \\
3\end{array}$ & $\begin{array}{l}<0.00 \\
1\end{array}$ & 0.023 & 1 & 3.416 & 0.065 \\
\hline $\begin{array}{l}\text { M. } \\
\text { thibetana }\end{array}$ & 0.103 & -0.955 & $\begin{array}{l}0.4 \\
8\end{array}$ & 0.003 & 0.029 & 1 & 0.562 & 0.454 \\
\hline $\begin{array}{l}\text { M. } \\
\text { nemestrina }\end{array}$ & 0.099 & -0.860 & $\begin{array}{l}0.5 \\
3\end{array}$ & $\begin{array}{l}<0.00 \\
1\end{array}$ & 0.021 & 1 & 1.931 & 0.166 \\
\hline M. leonina & 0.078 & -0.673 & $\begin{array}{l}0.3 \\
5\end{array}$ & $\begin{array}{l}<0.00 \\
1\end{array}$ & 0.000 & 1 & 0 & 0.990 \\
\hline $\begin{array}{l}\text { M. } \\
\text { sylvanus }\end{array}$ & 0.077 & -0.725 & $\begin{array}{l}0.3 \\
4\end{array}$ & 0.058 & 0.002 & 1 & 0.006 & 0.940 \\
\hline
\end{tabular}

John Wiley \& Sons, Inc. 
1

2

3

4

5

6

7

8

9

10

11

12

13

14

15

16

17

18

19

20

21

22

23

24

25

26

27

28

29

30

31

32

33

34

35

36

37

38

39

40

41

42

43

44

45

46

47

48

49

50

51

52

53

54

55

56

57

58

59

60

Table 6. Mahalanobis squared distances (below the diagonal) and Procrustes distances (above the diagonal) of the size- and sex-adjusted Procrustes shape coordinates between the species groups.

\begin{tabular}{lllll}
\hline & $\begin{array}{l}\text { fascicularis } \\
\text { group }\end{array}$ & $\begin{array}{l}\text { sinica } \\
\text { group }\end{array}$ & $\begin{array}{l}\text { silenus } \\
\text { group }\end{array}$ & $\begin{array}{l}\text { sylvanus } \\
\text { group }\end{array}$ \\
\hline fascicularis group & & 0.036 & 0.062 & 0.078 \\
sinica group & 3.226 & & 0.057 & 0.091 \\
silenus group & 3.862 & 3.512 & & 0.122 \\
sylvanus group & 6.684 & 7.620 & 8.148 & \\
\hline
\end{tabular}

All the differences were statistically significant $(\mathrm{p}<0.001)$. 
A

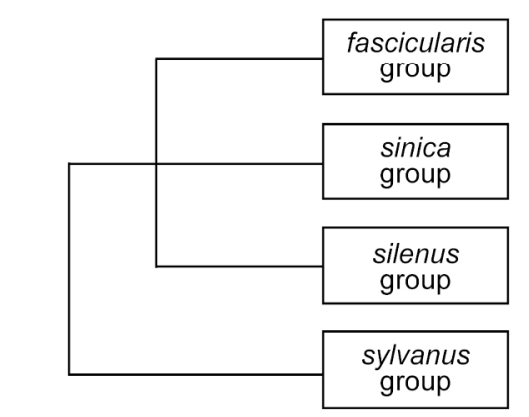

Morphology, biogeography, and fossil records

C

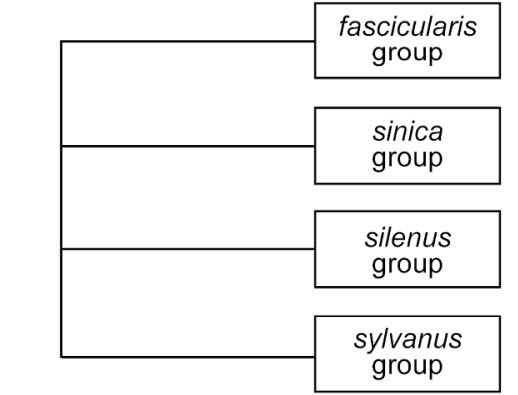

Y-chromosome DNA
B

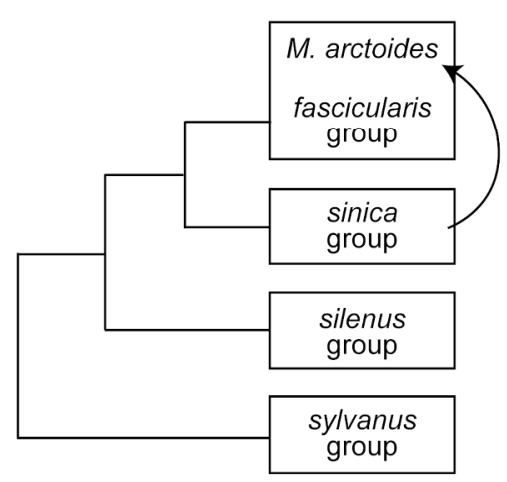

Mitochondrial DNA

D

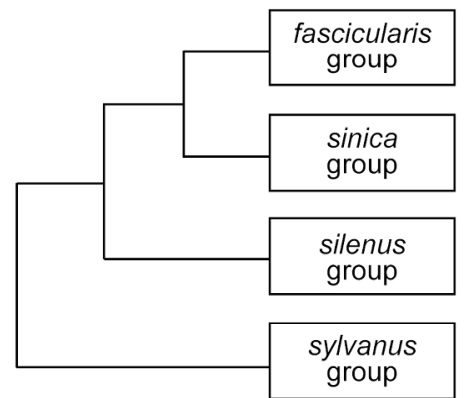

Alu elements

Figure 1

$196 \times 158 \mathrm{~mm}(300 \times 300$ DPI $)$

John Wiley \& Sons, Inc. 
A

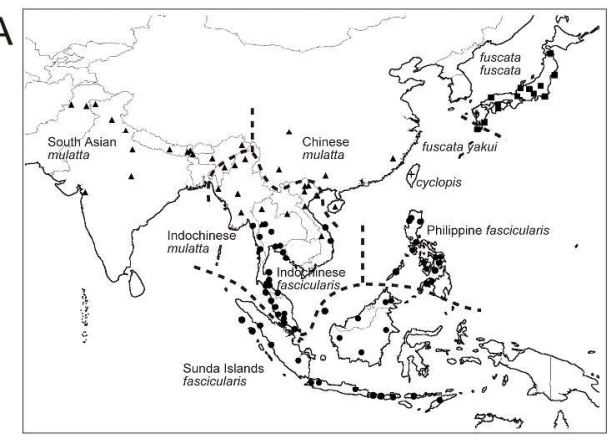

c

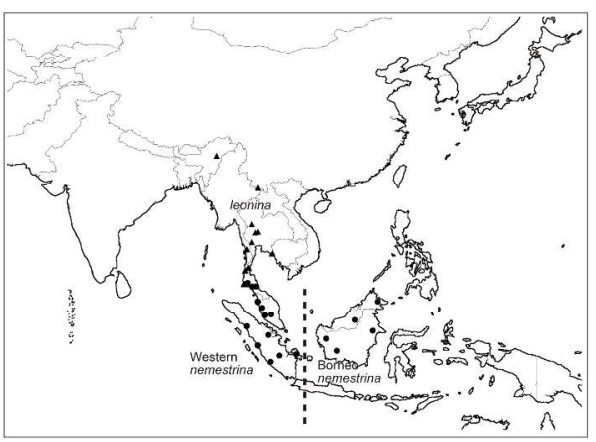

B

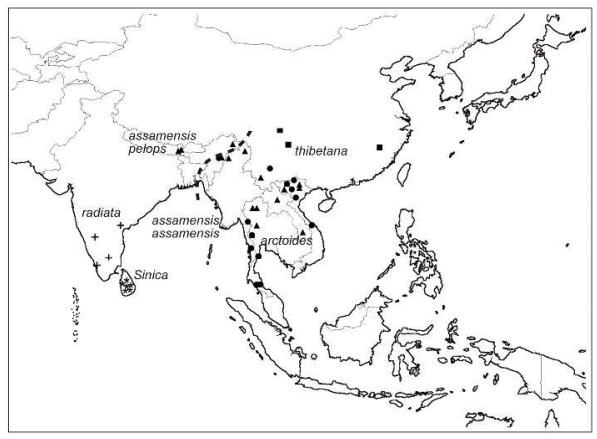

D

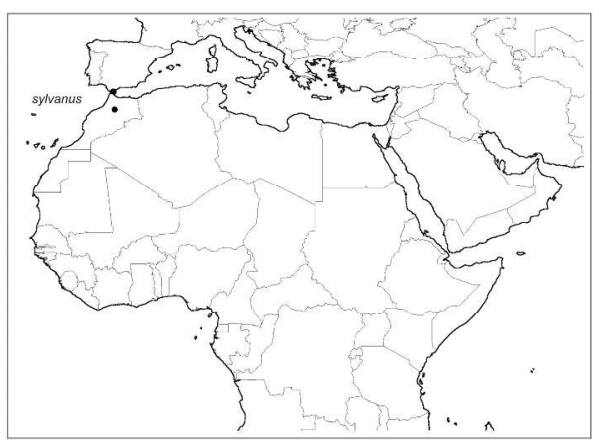

Figure 2

$286 \times 196 \mathrm{~mm}(300 \times 300$ DPI)

John Wiley \& Sons, Inc. 
A

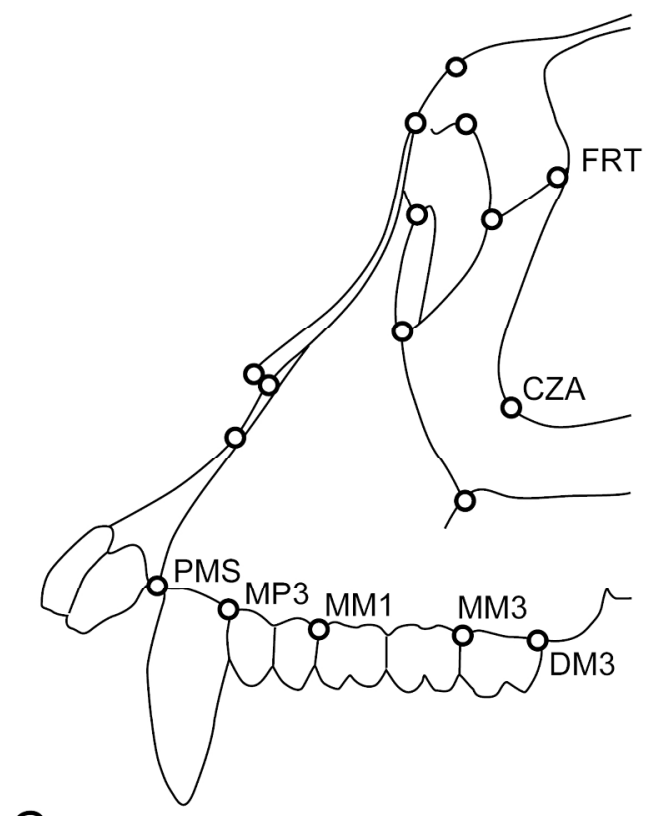

C

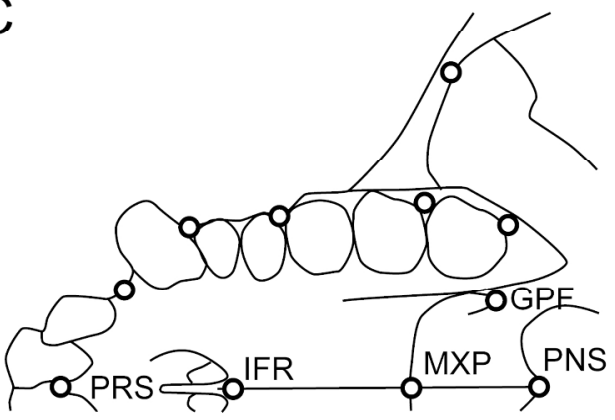

$\mathrm{B}$

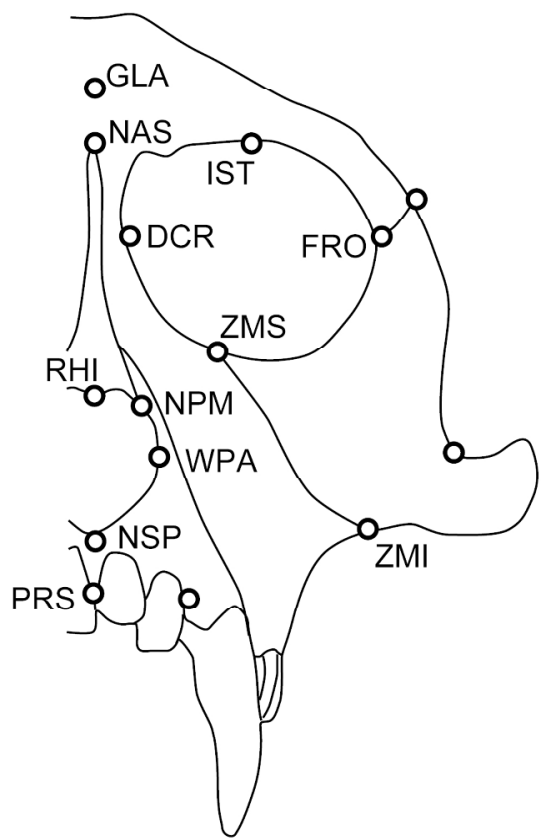

Figure 3

$202 \times 200 \mathrm{~mm}(300 \times 300$ DPI $)$

John Wiley \& Sons, Inc. 


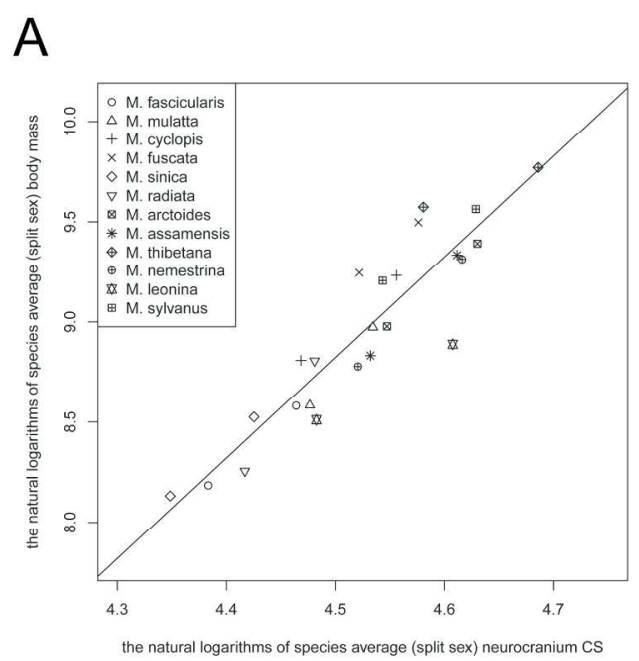

B

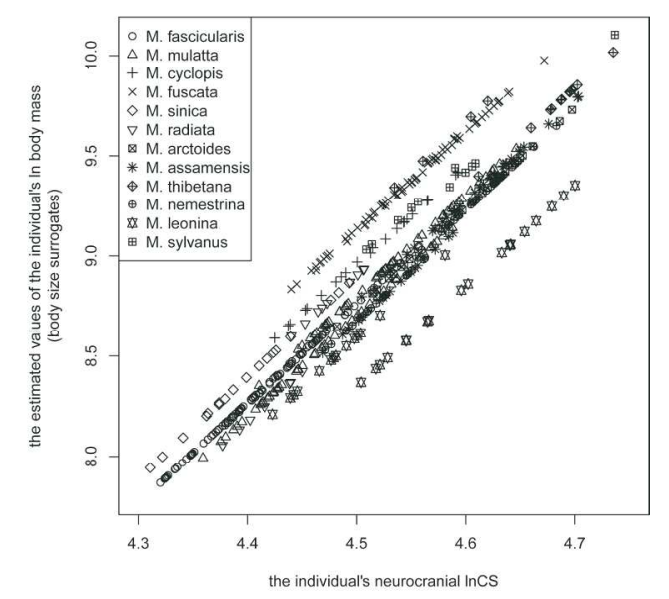

Figure 4

$209 \times 106 \mathrm{~mm}$ ( $300 \times 300$ DPI)

John Wiley \& Sons, Inc. 
A
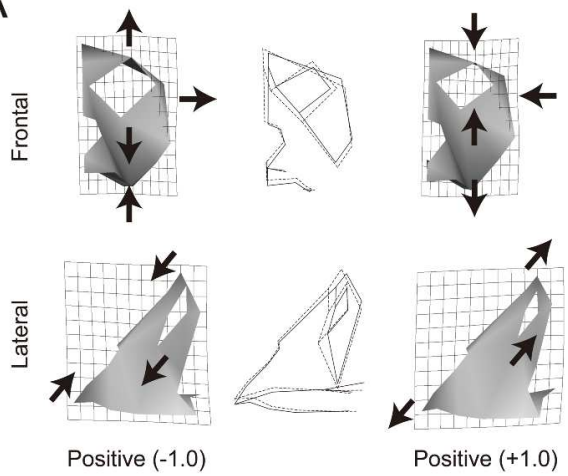

B

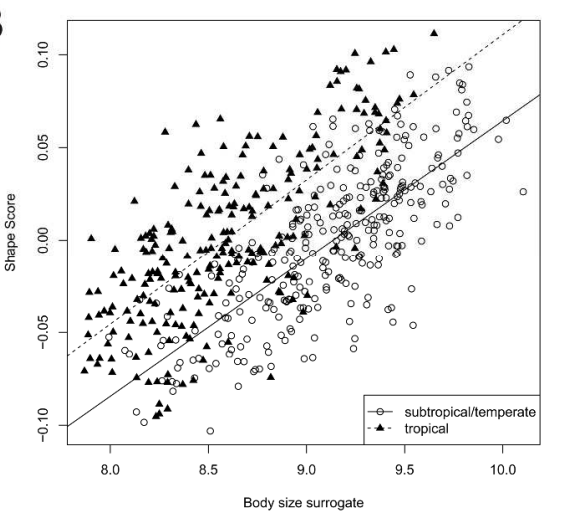

C

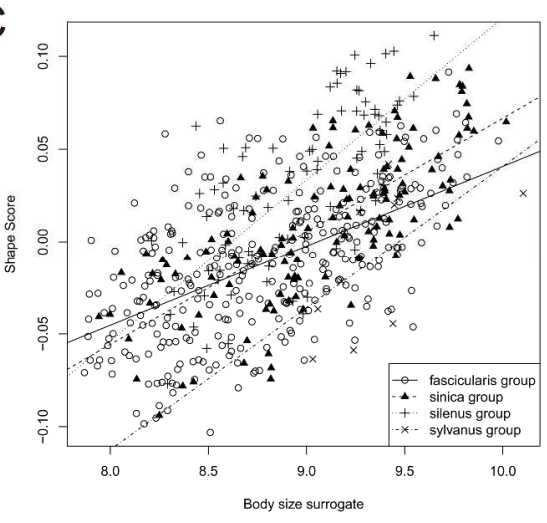

Figure $5 \mathrm{~A}-\mathrm{C}$

$293 \times 717 \mathrm{~mm}$ ( $300 \times 300$ DPI)

John Wiley \& Sons, Inc. 

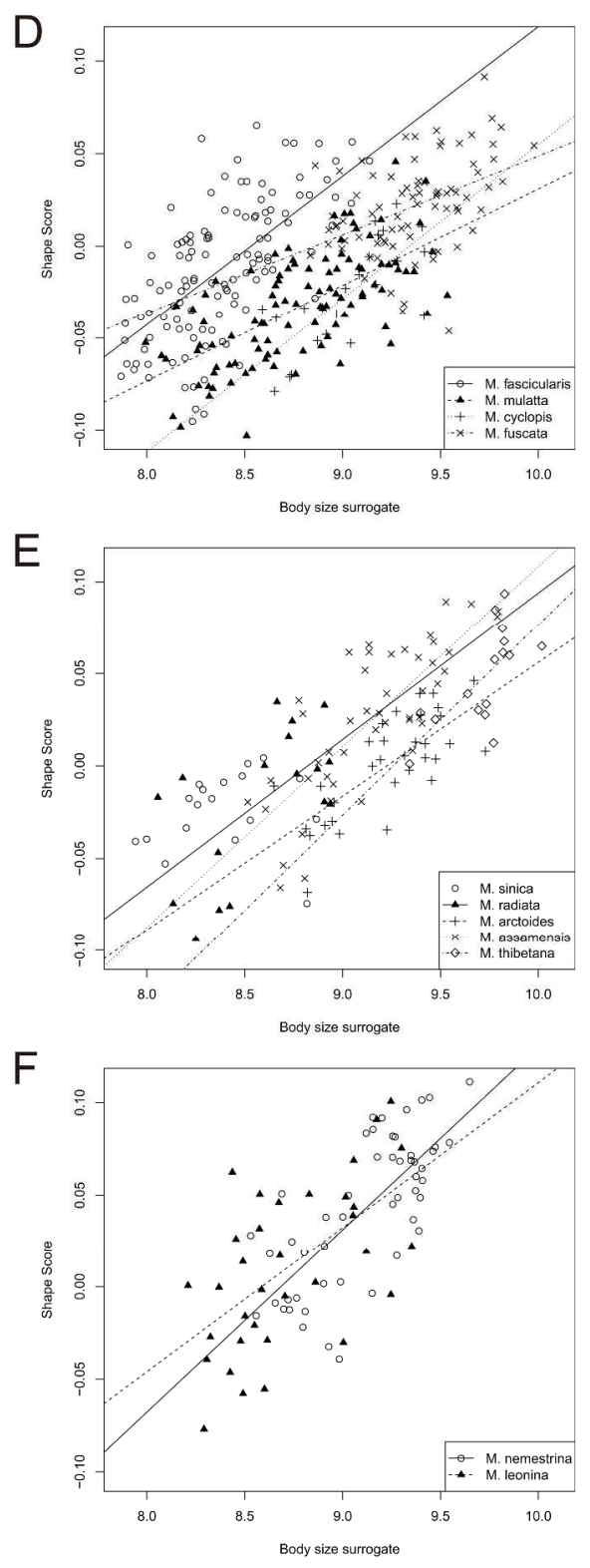

Figure 5D-F $293 \times 792 \mathrm{~mm}(300 \times 300$ DPI $)$

John Wiley \& Sons, Inc. 

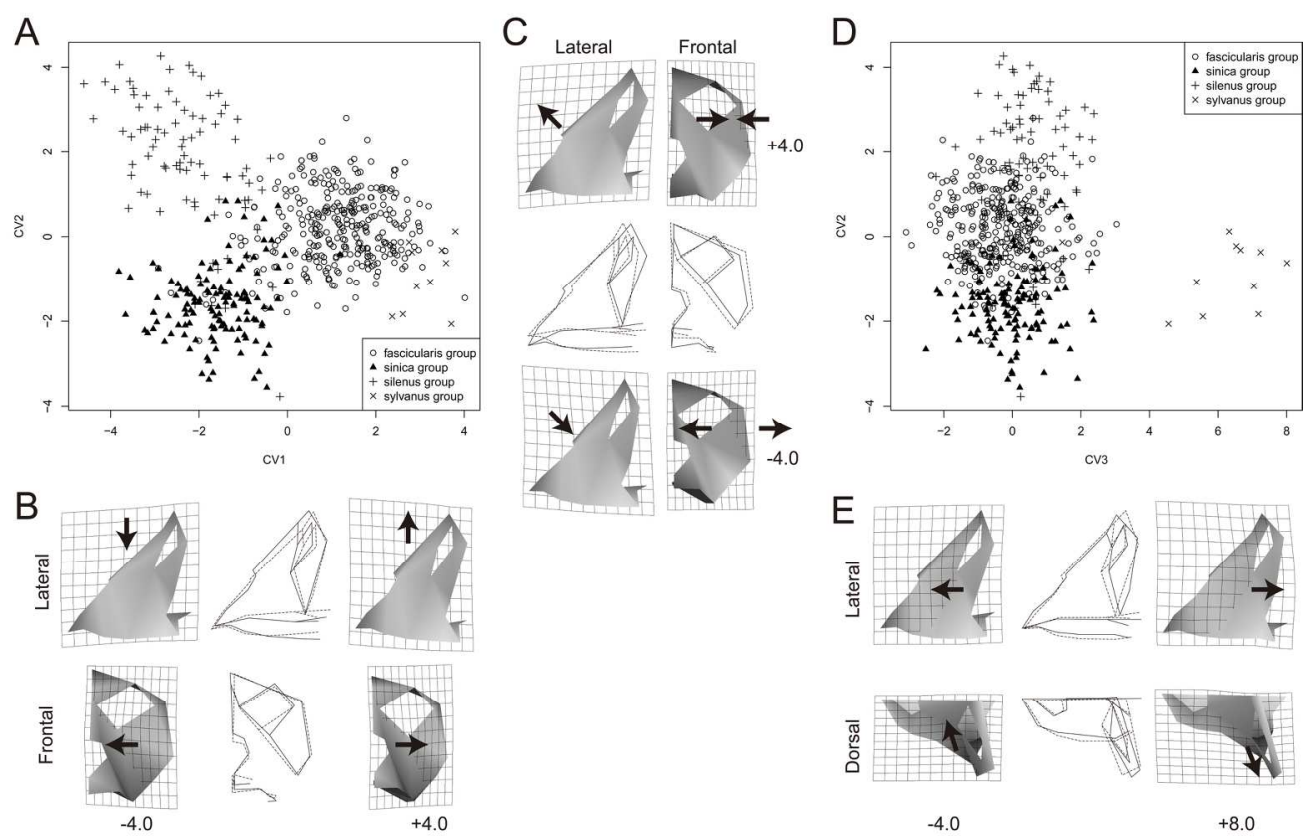

Figure 6

$188 \times 120 \mathrm{~mm}(300 \times 300 \mathrm{DPI})$

30

31

32

33

34

35

36

37

38

39

40

41

42

43

44

45

46

47

48

49

50

51

52

53

54

55

56

57

58

59

60

John Wiley \& Sons, Inc. 
A $\cong-\square$ Hard food eaters
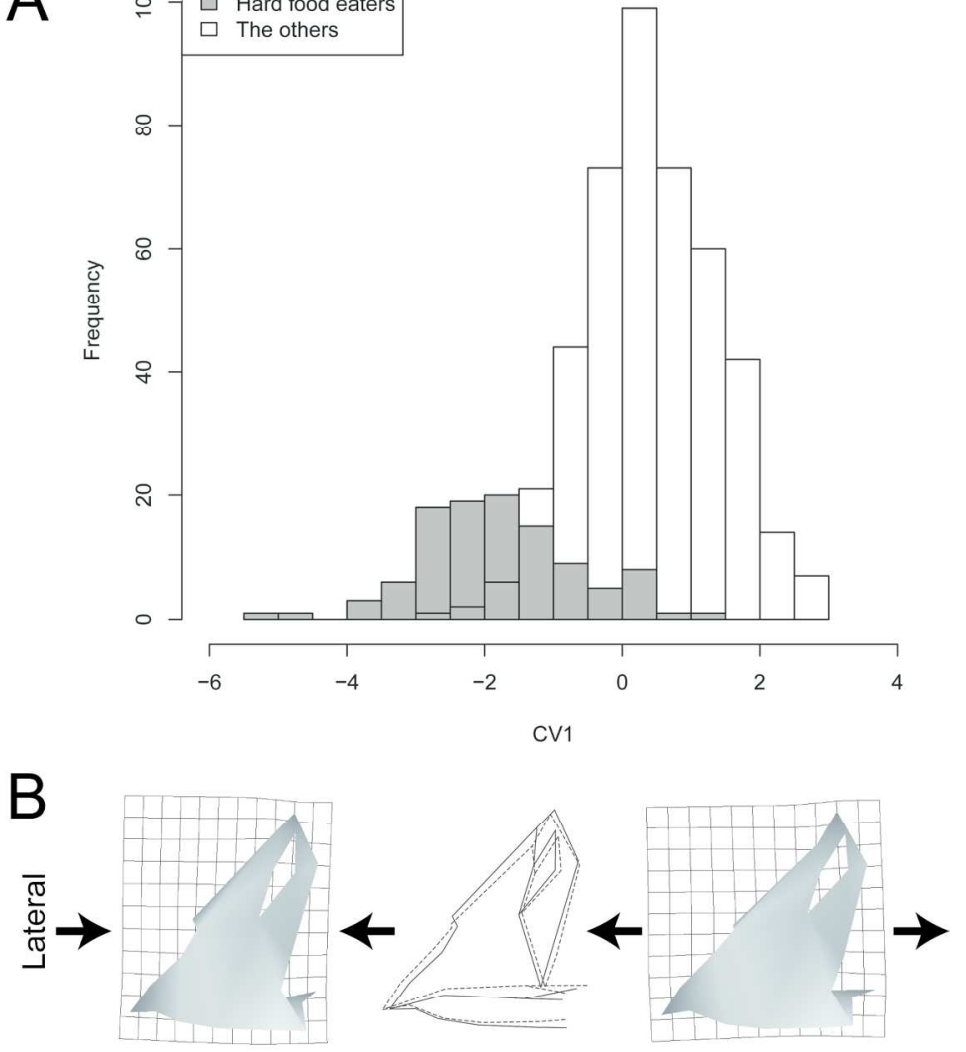

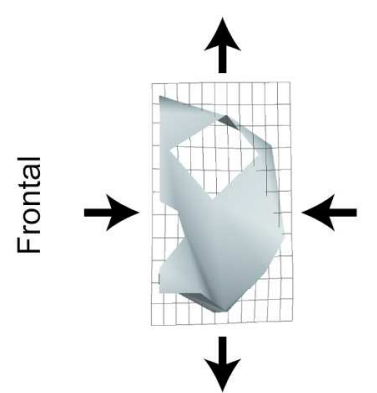

$-4.0$

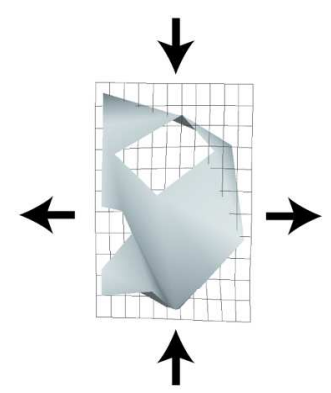

$+4.0$

Figure 7 $129 \times 208 \mathrm{~mm}(300 \times 300$ DPI $)$

John Wiley \& Sons, Inc. 


\section{Supporting information for Table 1: Ecogeographical and phylogenetic categories}

Fooden (1982a) suggested that Asian macaques are ecogeographically segregated into Southern tropical and Northern subtropical species, with a boundary occurring at approximately $18^{\circ} \mathrm{N}$ in both India and the Indochinese Peninsula. Based on this criterion, we defined five tropical species and seven subtropical/temperate species. Although the geographic range of $M$. arctoides extends southward beyond this boundary, we classified this species as subtropical/temperate (see Eudey, 1980; Fa, 1989; Fooden, 1990a).

The species distributed in the northern extremes of the macaques' distribution or in high mountain regions, namely $M$. fuscata, $M$. thibetana, and $M$. sylvanus, feed on considerable amounts of tough and/or fibrous foods (e.g., mature leaves, bark, and nuts) in certain seasons when the availability of more easily obtainable and nutritious food items (e.g., fruit) is limited (Izawa and Nishida, 1963; Suzuki, 1965; Zhao et al., 1991; Hanya, 2004; Hanya et al., 2011). These species were categorized as hard food eaters and were distinguished from the others.

For habitat use types, $M$. arctoides, $M$. nemestrina, and $M$. sylvanus were categorized as “terrestrial”; M. fascicularis, M. assamensis, and M. leonina were categorized as "arboreal”; and the others were categorized as intermediate or uncertain (Sugiyama, 1971; Fooden, 1975, 1979; Crockett and Wilson, 1980; Fooden, 1982a, 1985, 2000; Fooden and Wu, 2001; Chatani, 2003; Fooden, 2007).

The species group classification used in this study was based on that of Delson (1980) (Fig. 1A). Although there has been some debate concerning whether M. arctoides is more closely related to the sinica or fascicularis group (Morales and Melnick, 1998; Tosi et al., 2000, 2003) (Figs. 1B, C), a recent molecular study by Li et al. (2009) demonstrated strong statistical support for the placement of $M$. arctoides in the sinica group, confirming the classification by Delson (1980) (Fig. 1D). This result is robust because Alu elements used in this study showed very little homoplasy and their ancestral state is known (Li et al., 2009). 
Supporting information for Table 2: Samples used in this study

For the determination of sampling units on the basis of the distribution pattern and genetic divergence, we referred to the following literature: Fooden (1975, 1982b, 1990b, 1995, 2000), Tosi et al. (2002), Evans et al. (2003), Marmi et al. (2004), Fooden and Aimi (2005), Tosi and Coke (2007), Ziegler et al. (2007), Shiina et al. (2010). 


\section{Supporting information references}

Chatani K. 2003. Positional behavior of free-ranging Japanese macaques (Macaca fuscata).

Primates 44:13-23.

Crockett CM, and Wilson WL. 1980. The ecological separation of Macaca nemestrina and M.

fascicularis in Sumatra. In: Lindburg DG, editor. The macaques: Studies in ecology, behavior and evolution. New York: Nostrand-Reinhold. p 148-181.

Delson E. 1980. Fossil macaques, phyletic relationships and a scenario of deployment. In:

Lindburg DG, editor. The macaques: Studies in ecology, behavior and evolution. New York: Nostrand-Reinhold. p 10-30.

Eudey AA. 1980. Pleistocene glacial phenomena and the evolution of Asian macaques. In: Lindburg DG, editor. The macaques: Studies in ecology, behavior and evolution. New York: Nostrand Reinhold Ltd. p 52-83.

Evans BJ, Supriatna J, Andayani N, and Melnick DJ. 2003. Diversification of Sulawesi macaque monkeys: decoupled evolution of mitochondrial and autosomal DNA. Evolution 57:1931-1946.

Fa J. 1989. The genus Macaca: a review of taxonomy and evolution. Mamm Rev 19(2):45-81.

Fooden J. 1975. Taxonomy and evolution of liontail and pigtail macaques. Fieldiana Zool 67:1-169.

Fooden J. 1979. Taxonomy and evolution of the sinica group of macaques: 1 . species and subspecies accounts of Macaca sinica. Primates 20(1):109-140. 
Fooden J. 1982a. Ecogeographic segregation of macaque species. Primates 23(4):574-579.

Fooden J. 1982b. Taxonomy and evolution of the sinica group of macaques: 3. species and subspecies accounts of Macaca assamensis. Fieldiana Zool 10:1-52.

Fooden J. 1985. Taxonomy and evolution of the sinica group of macaques: 5. Overview of natural history. Fieldiana Zool 29:1-22.

Fooden J. 1990a. The bear macaques, Macaca arctoides: a systematic review. J Hum Evol 19:607-686.

Fooden J. 1990b. Systematic review of Philippine macaques (Primates, Cercopithecidae: Macaca fascicularis subspp.). Fieldiana Zool 64:1-44.

Fooden J. 1995. Systematic review of southeast Asian longtail macaques, Macaca fascicularis (Raffles, 1821). Fieldiana Zool 81(30):1-206.

Fooden J. 2000. Systematic review of the rhesus macaques, Macaca mulatta (Zimmermann, 1780). Fieldiana Zool 96(30):1-180.

Fooden J. 2007. Systematic review of the Barbary macaque, Macaca sylvanus (Linneaus, 1758). Fieldiana Zool 113(63):1-58.

Fooden J, and Aimi M. 2005. Systematic review of Japanese macaques, Macaca fuscata (Gray, 1870). Fieldiana Zool 104(14):1-200.

Fooden J, and Wu HY. 2001. Systematic review of the Taiwanese macaque, Macaca cyclopis Swinhoe, 1863. Fieldiana Zool 98(30):1-70. 
Hanya G. 2004. Diet of a Japanese macaque troop in the coniferous forest of Yakushima. Int J Primatol 25(1):55-69.

Hanya G, Menard N, Qarro M, Ibn Tattou M, Fuse M, Vallet D, Yamada A, Go M, Takafumi H, Tsujino R et al. . 2011. Dietary adaptations of temperate primates: comparisons of Japanese and Barbary macaques. Primates 52(2):187-198.

Izawa K, and Nishida T. 1963. Monkeys living in the northern limits of their distribution. Primates 4(2):67-88.

Li J, Han K, Xing J, Kim HS, Rogers J, Ryder OA, Disotell T, Yue B, and Batzer MA. 2009. Phylogeny of the macaques (Cercopithecidae: Macaca) based on Alu elements. Gene 448:242-249.

Marmi J, Bertranpetit J, Terradas J, Takenaka O, and Domingo-Roura X. 2004. Radiation and phylogeography in the Japanese macaque, Macaca fuscata. Mol Phylogen Evol 30:676-685.

Morales JC, and Melnick DJ. 1998. Phylogenetic relationships of the macaques (Cercopithecidae: Macaca), as revealed by high resolution restriction site mapping of mitochondrial ribosomal genes. J Hum Evol 34:1-23.

Shiina T, Tanaka K, Katsuyama Y, Otabe K, Sakamoto K, Kurata M, Nomura M, Yamanaka H, Nakagawa H, Inoko $\mathrm{H}$ et al. 2010. Mitochondrial DNA diversity among three subpopulations of cynomolgus macaques (Macaca fascicularis) originating from the 
Indochinese region. Exp Anim 5:567-578.

Sugiyama Y. 1971. Characteristics of the social life of bonnet macaques (Macaca radiata). Primates 12(3-4):247-266.

Suzuki A. 1965. An ecological study of wild Japanese monkeys in snowy areas: focused on their food habits. Primates 6(1):31-72.

Tosi AJ, and Coke CS. 2007. Comparative phylogenetics offer new insights into the biogeographic history of Macaca fascicularis and the origin of the Mauritian macaques. Mol Phylogen Evol 42:498-504.

Tosi AJ, Morales JC, and Melnick DJ. 2000. Comparison of Y chromosome and mtDNA phylogenies leads to unique inferences of macaque evolutionary history. Mol Phylogen Evol 17:133-144.

Tosi AJ, Morales JC, and Melnick DJ. 2002. Y-chromosome and mitochondrial markers in Macaca fascicularis indicate introgression with Indochinese $M$. mulatta and a biogeographic barrier in the isthmus of Kra. Int J Primatol 23(1):161-178.

Tosi AJ, Morales JC, and Melnick DJ. 2003. Paternal, maternal, and biparental molecular markers provide unique windows onto the evolutionary history of macaque monkeys. Evolution 57:1419-1435.

Zhao QK, Deng ZY, and Xu JM. 1991. Natural foods and their ecological implications for Macaca thibetana at Mount Emei, China. Folia Primatol (Basel) 57(1):1-15. 
Ziegler T, Abegg C, Meijaard E, Perwitasari-Farajallah D, Walter L, Hodges JK, and Roos C. 2007. Molecular phylogeny and evolutionary history of Southeast Asian macaques forming the M. silenus group. Mol Phylogen Evol 42:807-816. 